УДК 556.3(571.1)

\title{
ГИДРОГЕОЛОГИЯ И ГИДРОГЕОХИМИЯ МЕСТОРОЖДЕНИЯ РАДОНОВЫХ ВОД КАМЕНСКОЕ» (Г. НОВОСИБИРСК)
}

\author{
Новиков Дмитрий Анатольевич1,2, \\ NovikovDA@ipgg.sbras.ru
}

\section{Сухорукова Анна Федоровна ${ }^{1,2}$, SukhorukovaAF@ipgg.sbras.ru}

Корнеева Татьяна Владимировна', KorneevaTV@ipgg.sbras.ru

\section{Каменова-Тоцева Росица Михайлова ${ }^{3}$, r.totzeva@ncrrp.org}

\author{
Максимова Анастасия Алексеевна², \\ rock.nastaya64@gmail.com
}

\author{
Деркачев Антон Сергеевич2, \\ a.derkachev@g.nsu.ru
}
Дульцев Федор Федорович 1 , DultsevFF@ipgg.sbras.ru

\section{Черных Анатолий Витальевич 1 ChernykhAV@ipgg.sbras.ru}

\footnotetext{
1 Институт нефртегазовой геологии и геофизики им. А.А. Трофимука СО РАН, Россия, 630090, г. Новосибирск, пр. Академика Коптюга, 3/6.

2 Новосибирский национальный исследовательский государственный университет, Россия, 630090, г. Новосибирск, ул. Пирогова, 1.

3 Национальный центр радиобиологии и радиационной защиты, Болгария, 1606, г. София, ул. «Св. Георгия Софийского», 3.
}

\begin{abstract}
Актуальность исследования состоит в получении новых сведений о гидрогеологии и гидрогеохимии слабоизученных месторождений радоновых вод города Новосибирска на юге Западной Сибири. Новосибирск относится к числу тех немногих городов России, которые были заложены на гранитах - источнике эманации радона (222Rn). B геологическом отношении изучаемая территория приурочена к внутренней области крупного Новосибирского гранитоидного массива. Научных обобщений имеющегося фактического материала не проводилось.

Цель: выявление особенностей гидрогеологического строения и гидрогеохимии месторождения радоновых вод «Каменское», изучение форм миграции химических элементов в водах и оценка степени их насыщения относительно ряда карбонатных, сульфатных и силикатных минералов.
\end{abstract}

Методы. Отбор проб выполнялся в соответствии с общепринятыми методиками. Обобщение и анализ гидрогеохимических данных проводилось с применением программных средств Microsoft Excel, STATISTICA, SURFER, Grid Master. B cpede программных комплексов Visual Minteq и WATEQ4f выполнены ффизико-химические расчеты форм миграции химических элементов в радоновых водах и степени их насыщения к ряду породообразующих минералов.

Результаты: В гидрогеологическом разрезе месторождения радоновых вод «Каменское» геологоразведочными работами установлено два водоносных комплекса (сверху вниз): поровых вод четвертичных отложений и трещинно-жильных вод верхнепалеозойских гранитов. В условиях Центрального района города Новосибирска, где почти вся площадь поверхности покрыта ассральтом и занята под сооружения и инсрильтрация атмосфрерных осадков осложнена, естественный режим питания подземньх вод нарушен. Порово-пластовые воды четвертичных отложений, воды зоны региональной трещиноватости и трещинно-жильные воды верхнепалеозойских гранитов находятся в единой области смешения, на которую оказывают влияние процессы подтопления и антропогенного загрязнения. В этой связи в водоносном комплексе верхнепалеозойских гранитов выделяется две гидрогеохимической зоны: верхняя - воды зоны региональной трещиноватости в зоне подтопления в условиях антропогенного воздействия, и нижняя - трещинно-жильные минеральные радоновые воды. Минеральные радоновые трещинно-жильные воды гранитов, не подверженнье антропогенному влиянию установлены в скв. 4n (интервал 73-74 м) и в скв. 16 на глубинах от 73 до 128 м. Они холодные собственно пресные $\mathrm{HCO}_{3} \mathrm{Na}-\mathrm{Ca}$ и $\mathrm{HCO}_{3} \mathrm{Na}-\mathrm{Mg}$-Са состава с величиной общей минерализации от 613,4 до 689,9 ме/дм с содержанием кремния 10,3-13,6 ме/дм³. Они характеризуются рH от нейтральных до слабощелочных (6,9-7,8), кислородно-азотным составом водорас-

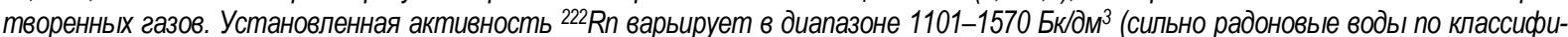

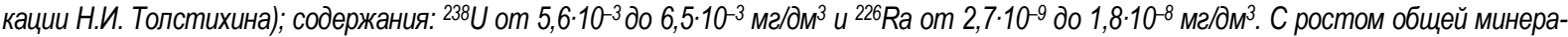
лизации радоновых вод доля простых катионных форм $\mathrm{Mg}^{2+}, \mathrm{Ca}^{2+}, \mathrm{Na}^{+}, \mathrm{Sr}^{2+}, \mathrm{Ba}^{2+}$ в растворе уменьшается, это связано с образованием труднорастворимых карбонатных и сульфатных соединений. В радоновых водах фоормы $\mathrm{Fe}(\mathrm{Il})$ представлены в виде $\mathrm{Fe}^{2+}, \mathrm{FeHCO}_{3}{ }^{+}$, $\mathrm{FeCO}_{3}{ }^{0}$. $\mathrm{Fe}(\mathrm{III})$ мигрирует в фороре положительно заряженных гидроксокомплексов $\mathrm{Fe}(\mathrm{OH}) 2^{+}$и нейтральных $\mathrm{Fe}(\mathrm{OH})_{3}{ }^{0}$. Cреди фоорм миграции марганца доминирует простой катион $\mathrm{Mn}^{2+}$ (43,71-99,99 \%), остальные формы представлены $\mathrm{MnHCO}_{3}{ }^{+}(9,89-28,27$ \%), $\mathrm{MnCO}_{3}{ }^{0}(0,01-37,39)$, еще в меньшей степени $\mathrm{MnSO}_{4}{ }^{0}(0,20-2,25 \%), \mathrm{MnCl}^{+}(0,04-1,12 \%)$ и MnOH+ $(0,01-0,05 \%)$. Химические фрормы миграции тяжелых металлов (никеля и меди) представлены в виде свободных катионов $\left(\mathrm{Ni}^{2+}, \mathrm{Cu}^{2+}\right)$, гидрокарбонатных $\left(\mathrm{NiHCO}_{3}\right.$, $\left.\mathrm{CuHCO}_{3}{ }^{-}\right)$и карбонатных $\left(\mathrm{NiCO}_{3}{ }^{0}, \mathrm{CuCO}_{3}{ }^{\circ}\right)$ комплексов. Медь также мигрирует в нейтральной форрме $\mathrm{Cu}(\mathrm{OH}) 2_{2}{ }^{0}$. Бериллий $(1$ класс опасности) мигрирует в форме гидроксокомплекса $\mathrm{Be}(\mathrm{OH})_{2}$. Установленнье особенности геохимических типов вод, долевого распределения форм и коэфффициентов водной миграции химических элементов выявили усложнение состава равновесных минералов от сидерита, ферригидрита и гриналита в поверхностных водах до их насыщения кальцитом, доломитом, магнезитом, родохрозитом и тальком в трещинно-жильных водах верхнепалеозойских гранитов. Формы миграции химических элементов обуславливают механизмы растворения/осаждения минеральных соединений.

\section{Ключевые слова:}

Гидрогеохимия, радоновые воды, уран, радий, радон, микрокомпоненты, фформы миграции, индексы насьщения, месторождение радоновых вод «Каменское», город Новосибирск, Западная Сибирь. 


\section{Введение}

Настоящая работа продолжает серию статей [1-5], посвященных радоновым водам города Новосибирска. Большая часть исследуемой территории расположена на гранитах одноименного массива (рис. 1).

Радоновые воды имеют широкое распространение на Земле с максимально известными к настоящему времени концентрациями радона до 182000 Бк/дм [6-23]. Ранее в научной литературе отмечалось, что Новосибирские радоновые воды в России являются наименее изученными [24-28]. История их изучения СУ «Енисейстрой» МВД СССР начинается с 1945 г. и в дальнейшем связана с Березовской экспедицией. В результате этих работ недалеко от города было открыто Пригородное месторождение урана [29, 30].

В связи с открытием в 1974 г. радоновых вод санатория «Заельцовский бор», который значительно удален от центра города, городскими властями в 1982 г. было запланировано строительство «Горводолечебницы» в районе станции Скорой помощи в квартале между улицами Ольги Жилиной, Фрунзе, Семьи Шамшиных и долиной р. Каменки, которое так и не было осуществлено. Геологоразведочные работы на месторождении «Каменское» проводила Новосибирская геолого-поисковая экспедиция производственного объединения «Новосибирскгеология», под руководством старшего гидрогеолога Е.К. Вериго. В изучении месторождения принимали участие гидрогеологи С.В. Шабанов, И.П. Карпинский, Г.Л. Самсонов, Т.В. Терехова, Е.П. Виценко, Н.Н. Бусоргина, М.Н. Козлова, В.П. Мочалов и другие.

В геоморфологическом отношении изучаемый участок приурочен к участку Заобской расчлененной равнины с врезанной в нее долиной реки Каменка (правый приток реки Обь). Равнина полого снижается к долине реки Каменка от абсолютных отметок 160 м до 140-130 м и в естественном состоянии круто обрывалась в долину уступами высотой до 20 м. В настоящее время выполнено инженерное улучшение поверхности участка, крутые склоны срезаны, а пойма р. Каменки и прилегающие овраги замыты песком. Русло р. Каменки спрямлено и проложено в бетонных трубах. В конце 1970-х гг. в городе Новосибирске были выполнены поисковые работы на радоновые воды, на исследуемом участке была пробурена скважина № 4 глубиной 172,2 м и гипсометрически ниже на борту р. Каменки - скважина № 11п глубиной 81,4 м. Обе скважины вскрыли радоновые воды, в которых были проведены комплексные радиогидрогеологические исследования.

Месторождение «Каменское» расположено в густо застроенном Центральном районе города Новосибирска и приурочено к одноименному массиву верхнепалеозойских гранитов (рис. 1), залегающих на глубинах около 50 м. Радоновые воды месторождения подвержены значительному антропогенному загрязнению за счет процессов подтопления, которые затронули четвертичные отложения и зону региональной трещиноватости гранитов. Минеральные радоновые трещинно-жильные воды гранитов, не подверженные антропогенному влиянию, установлены в скв. 4п (интервал 73-74 м) и в скв. 16 на глубинах от 73 до 128 м. Они холодные собственно пресные $\mathrm{HCO}_{3}$ $\mathrm{Na}-\mathrm{Ca}$ и $\mathrm{HCO}_{3} \mathrm{Na}-\mathrm{Mg}-\mathrm{Ca}$ (в формуле М.Г. Курлова учтены компоненты $>10$ \%-экв.) состава с величиной общей минерализации от 613,4 од 689,9 мг/дм³ с содержанием кремния 10,3-13,6 мг/дм³. Они характеризуются значениями рН от нейтральных до слабощелочных $(6,9-7,8)$, кислородно-азотным составом водорастворенных газов. Установленная активность ${ }^{222} \mathrm{Rn}$ варьируют в диапазоне 1101-1570 Бк/дм ${ }^{3}$; содержания: ${ }^{238} \mathrm{U}$ от $5,6 \cdot 10^{-3}$ до $6,5 \cdot 10^{-3}$ мг/дм ${ }^{3}$ и ${ }^{226} \mathrm{Ra}$ от $2,7 \cdot 10^{-9}$ до $1,8 \cdot 10^{-8}$ мГ/дм

\section{Фактический материал и методика исследования}

С 2017 г. в лаборатории гидрогеологии осадочных бассейнов Сибири Института нефтегазовой геологи и геофизики им. А.А. Трофимука СО РАН начаты работы по архивации, а с 2019 г. - комплексные полевые исследования радоновых вод Новосибирской области. В течение этого периода для детальных изотопногидрогеохимических исследований отобрано более 150 проб. Отбор проб, предварительная пробоподготовка выполнялись в соответствии с общепринятыми методиками. Изучение быстроизменяющихся параметров - с помощью полевой гидрогеохимической лаборатории и полевого оборудования (Hanna HI9125, кислородомер АКПМ-1-02Л), выполнялось полевое определение общей минерализации вод (кондуктометр S3-Field kit Seven2Go, Mettler Toledo). Радиационная обстановка на месте отбора проб оценивалась с помощью дозиметра гамма-излучения ДКГ-07Д Дрозд. Изучение содержаний радона в воде проводилось комплексом для мониторинга радона, торона и их дочерних продуктов «Альфарад плюс».

Массив гидрогеохимических данных по месторождению «Каменское» представлен 49 пробами, а общий банк данных - более 1300 записями. Изучение гидрогеохимических данных проводилось в среде программ Microsoft Excel, STATISTICA, SURFER, Grid Master. При помощи Visual Minteq и WATEQ4f выполнены физико-химические расчеты форм миграции химических элементов в радоновых водах и степени их насыщения к ряду породообразующих минералов. Название химического типа вод дано с учетом $>10 \%$-экв в порядке возрастания.

Использование геохимических коэффициентов ( $\mathrm{Ca} / \mathrm{Na}, \mathrm{Ca} / \mathrm{Mg}, \mathrm{Ca} / \mathrm{Si}, \mathrm{Mg} / \mathrm{Si}, \mathrm{Na} / \mathrm{Si}, \mathrm{Si} / \mathrm{Na}, \mathrm{rNa} / \mathrm{rCl}$ и $\mathrm{SO}_{4} / \mathrm{Cl}$ ) позволило разделить имеющиеся данные на однородные геохимические совокупности по процессам формирования их состава (гидролиз алюмосиликатов, окисление сульфидных минералов, антропогенное влияние).

\section{Результаты исследования и обсуждение}

\section{Гидрогеологические условия}

Месторождение радоновых вод «Каменское» приурочено к внутренней области Новосибирского гранитоидного массива (рис. 1), особенности геологического строения которого обобщены нами ранее [1]. 


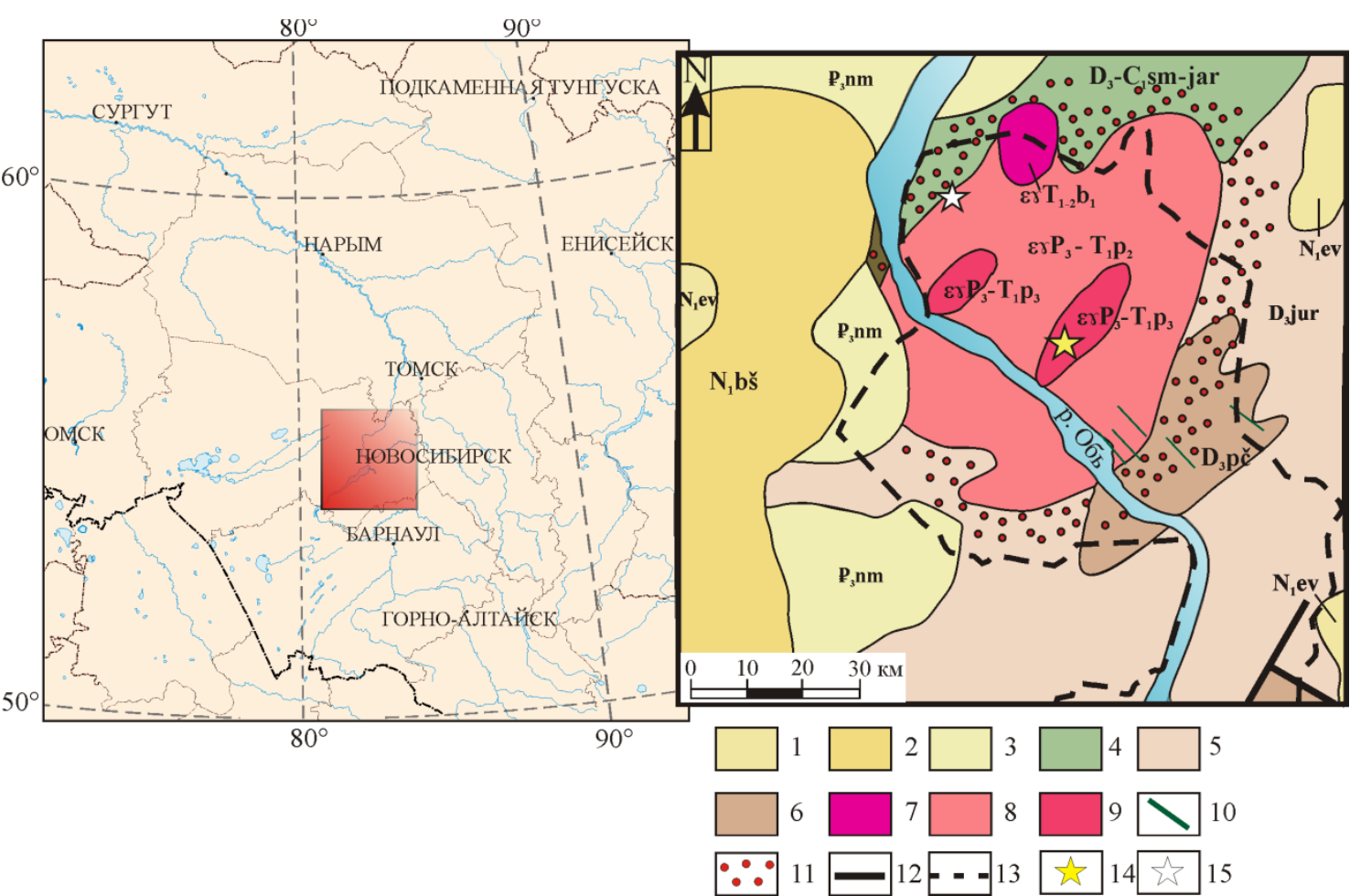

Рис. 1. Местоположение района исследований (по [31]). 1 - евсинская свита (N ${ }_{1}$ ev) - глины мраморовидные пестроокрашенные; 2 - бещеульская свита $\left(N_{l} b 5 ̌\right)$ - алевриты с прослоями глинистых песков, гравия, галечников; 3 новомихайловская свита $\left(P_{3} n m\right)$ - переслаивание песков, алевритов, бурых глин, лигнитовых углей; 4 - саламатовская и ярская толщи нерасчлененные (D $-C_{l}$ sm-jar); 5 - юргинская свита $\left(D_{3} j u r\right)$ - песчаники серые полимиктовые, в нижней части известковые, сланцы глинистые, алевролиты, прослои гравелитов и известняков; 6 - пачинская свита $\left(D_{3}\right.$ рс̌) - сланиы глинистые темно-серые, алевролиты, прослои песчаников, пачки известняков; Барлакский гранит-лейкогранитовый мезоабиссальный комплекс: 7 - первая фаза, мониолейкограниты и лейкограниты биотитовые среднезернистые, реже монцограниты биотитовые и амфиболбиотитовые (عг $\left.T_{1-2} b_{1}\right)$; Приобский мониодиорит-гранодиоритовый мезоабиссальныий комплекс: 8 - вторая фаза, монцограниты, граносиениты, граниты, гранодиориты амфиболовые среднезернистые, порфировид-

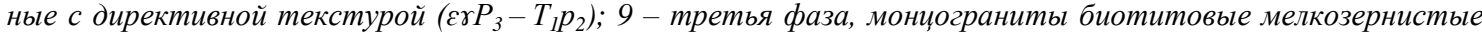
$\left(\varepsilon r P_{3}-T_{1} p_{3}\right) ; 10$ - дайки спессартитов, квариевых монцодиорит-порфиритов; 11 - контактовые роговики и ороговикованные породы; 12 - разломы; 13 - граница г. Новосибирска; 14 - район исследований; 15 - Заельиовское месторождение минеральных радоновых вод

Fig. 1. Location of the research area (by [31]). 1 - Evsinskaya Formation $\left(N_{l} e v\right)$ - marble-shaped multi-colored clays; 2 Bescheuli Formation $\left(N_{l} b s ̌\right)$ - siltstones with interlayers of clay sands, gravel, pebbles; 3 - Novomikhailovskaya Formation $\left(P_{3} \mathrm{~nm}\right)$ - interlayering of sands, silts, clays and lignite coals $(10-120 \mathrm{~m}) ; 4$ - Salamat and Yar strata (not divided) $\left(D_{3}-C_{l}\right.$ sm-jar); 5 - Yurga Formation ( $\left.D_{3} j u r\right)$ - gray polymictic sandstones, calcareous in the lower part, clay shales, siltstones, interlayers of gravelites, limestones; 6 - Pachinsky Formation $\left(D_{3} p c ̌\right)$ - dark gray clay shales, siltstones, sandstone beds, limestone packs; Barlak granite-leucogranite meso-abyssal complex: 7 - first phase, monzole granites and medium-grained biotite leucogranites, less often biotite and amphibole-biotite monzogranites $\left(\varepsilon r T_{1-2} b 1\right)$; Priobsky monzodiorite-granodiorite meso-abyssal complex: 8 - second phase, monzogranites, granosyenitis, granites, amphibole granodiorites, medium-grained, porphyritic with directive texture $\left(\varepsilon r P_{3}-T_{1} p_{2}\right) ; 9-$ third phase: fine-grained monzogranites $\left(\varepsilon r P_{3}-T_{1} p_{3}\right) ; 10$-dykes of spessartites, quartz monzodiorite-porphyrites; 11 contact hornfelses and hornfelsed rocks; 12 - faults; 13 - Novosibirsk city boundary; 14 - research area; 15 «Zaeltsovskoe» mineral radon field

В гидрогеологическом разрезе месторождения минеральных радоновых вод «Каменское» геологоразведочными работами установлено два водоносных комплекса. Верхний представлен поровыми водами четвертичных отложений. Ниже залегает водоносный комплекс, включающий воды зоны региональной трещиноватости и трещинно-жильные воды верхнепалеозойских гранитов (рис. 2, 3). Подобные гидрогеологические условия характеризуют большую часть города Новосибирска. Двухъярусный гидрогеологический разрез широко развит в прибортовых районах артезианских бассейнов [32-37].
Водоносный комплекс порово-пластовых вод четвертичных отложений представлен глинистопесчаными отложениями водоносного горизонта краснодубровской свиты нижне-среднечетвертичного возраста и песчаными аллювиальными отложениями водоносного горизонта верхнечетвертичного возраста, слагающими первую надпойменную террасу и пойму реки Каменка. Водоносный комплекс изучен бурением скважинами № 15, 16, 17, 21, 22 и 11п. Мощность четвертичных отложений закономерно уменьшается к пойме реки Каменка от 55 м в скважине 17 до 30 м в скважине 11п (рис. 3). 


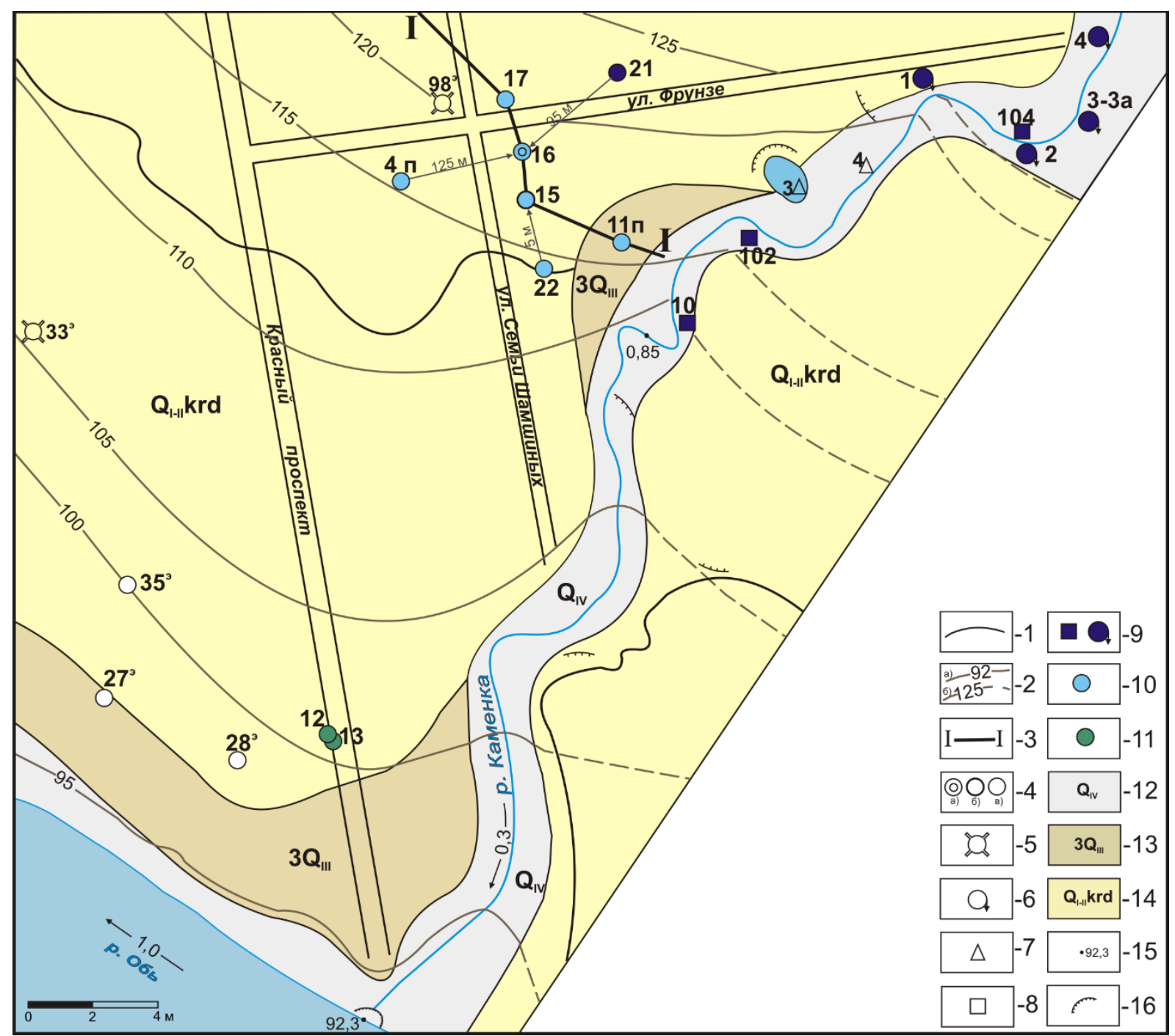

Рис. 2. Гидрогеологическая карта месторождения «Каменское»: 1 - границы первых от поверхности водоносных горизонтов; 2 - гидроизогипсы: а) установленные, б) предполагаемые; 3 -линия гидрогеологического разреза; 4 - скважины: а) разведочно-эксплуатационная, б) разведочная, в) поисковая; 5 - скважсина эксплуатационная (ликвидированная); 6 - родник; 7 -место отбора проб воды из поверхностных водоемов; 8 - колодиь;; Типы вод по концентрации радона (по Н.И. Толстихину): 9 - очень слаборадоновые: 37-185 Бк/дм ; 10 - уме-

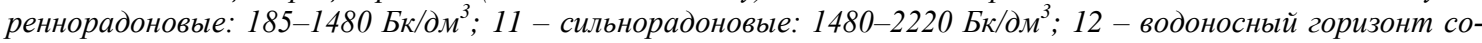
временных отложений пойменных террас р. Оби и р. Каменки (пески, супеси, суглинки); 13 - водоносный горизонт верхнечетвертичных отложений третьей надпойменной террасы р. Оби и р. Каменки (пески, суглинки); 14 - водоносный горизонт нижне-средне-четвертичных отложений краснодубровской свиты (пески, суглинки, глины); 15 - абсолютная отметка уровня водоема; 16 - выходы гранитов на дневную поверхность

Fig. 2. Hydrogeological map of the "Kamenskoe» field: 1 - boundaries of the first aquifers from the surface; 2 - hydroisohypses: a) established, b) alleged; 3 - line hydrogeological section; 4 - wells: a) exploration and production, b) exploration, c) prospect; 5 -production well (abandoned); 6 - spring; 7 - place of sampling; 8 -wells; Types of water according to the concentration of radon (according to N.I. Tolstikhin): 9 - very low radon: 37-185 Bq/ $\mathrm{dm}^{3}$; 10 - moderately radon: $185-1480 \mathrm{~Bq} / \mathrm{dm}^{3} ; 11$ - radon: $1480-2220 \mathrm{~Bq} / \mathrm{dm}^{3} ; 12$ - aquifer of modern sediments of floodplain bench of the river $\mathrm{Ob}$ and river Kamenka (sand, sandy loam, loam); 13 - aquifer of the Upper Quaternary sediments of the third floodplain bench of the river $\mathrm{Ob}$ and river Kamenka (sand, loam); 14 - aquifer of the lowermid-Quaternary sediments of the Krasnodubrovskaya Formation (sands, loams, clays); 15 - absolute reservoir elevation; 16 - granites outcrop

Река Каменка дренирует подземные воды водоносного комплекса четвертичных отложений. Водоносный горизонт краснодубровской свиты в изучаемом районе имеет преимущественно песчаный состав, лессовые суглинки и супеси имеют подчиненное значение. Суглинки залегают в виде линз и прослоев мощностью до 15 м, супеси мощностью до 15 м зале- гают в верхней части разреза и включают прослои песков мощностью до первых метров. Абсолютные отметки зеркала подземных вод комплекса закономерно снижаются в направлении реки Каменка и изменяются от 122,8 м в скважине 21 до 114,1 м в скважине 11п. Породы комплекса залегают на сильно эродированной поверхности Новосибирскому грани- 
тоидного массива. Подземные воды безнапорные, питание водоносного горизонта инфильтрационное. Дебиты скважин составляют 0,15-0,81 л/с. Воды подвержены значительному антропогенному влиянию за счет процессов подтопления. По химическому составу воды они варьируют от $\mathrm{Cl}-\mathrm{HCO}_{3} \mathrm{Na}-\mathrm{Mg}-\mathrm{Ca}$ до $\mathrm{NO}_{3}-\mathrm{Cl}-\mathrm{HCO}_{3} \mathrm{Na}-\mathrm{Ca}$ с величиной общей минерализации до 1800 мг/дм ${ }^{3}$ с содержанием урана $9,75 \cdot 10^{-5}-7,8 \cdot 10^{-3}$ мг/дм ${ }^{3}$, радия $1,3-17,0 \cdot 10^{-9}$ мг/дм ${ }^{3}$ и активностью радона 163,2-389,4 Бк/дм ${ }^{3}$.

Водоносный комплекс верхнепалеозойских гранитов представлен водами зоны региональной трещиноватости и трещинно-жильными водами. Поверхность гранитного батолита неровная, вскрывается скважинами на глубинах от 30 до 70 м. Самая глубокая на месторождении скважина № 16 вскрыла граниты до абс. отметки -18 м (рис. 3). Граниты от светлосерых до розовых, мелко-среднезернистые кварцполевошпатового состава, иногда с примесью биотита. Граниты трещиноватые, на стенках трещин наблюдаются включения сульфидов (пирит, молибденит) и флюорита. В гранитах различается несколько генера- ций трещин: 1) наиболее древние трещины залечены хлоритом, сульфидами, флюоритом, кварцем (они хорошо различаются в керне скважин, пересекают его под углами 45-60); 2) трещины закальматированные продуктами химического выветривания гранитов (скв. 16, интервалы: 98,6-99; 100,3-100,6 и 168-171 м); 3) трещины закальматированные гидроокислами железа (скв. 16, интервал: 70,5-76,4 м) и 4) открытые трещины, по которым происходит циркуляция радоновых вод. В гидрогеологическом разрезе по данным расходометрического каротажа и материалам поинтервальных и пробных (опытных) откачек отмечается высокая неоднородность водоносности и водообильности зон трещиноватости гранитов. Так, в скважине № 15 водообильные зоны установлены в интервалах: $47-48,5 ; 50-54 ;$ 62-64; 72-76; 81-86; 87-96 и 110-117 м; в скважине № 16 - в интервалах: 74-75; 82-84; $86,5-87,5 ; 91-92 ; 104-108$ и 127-128 м и т. д. Притоки воды в скважины составляют 0,08-1,6 л/с из разных зон при суммарных 0,44-2,66 л/с. Дебиты варьируют в интервале 1,2-2,7 л/с при понижениях 0,8-26 м, а удельные дебиты составляют 0,05-1,6 л/с.

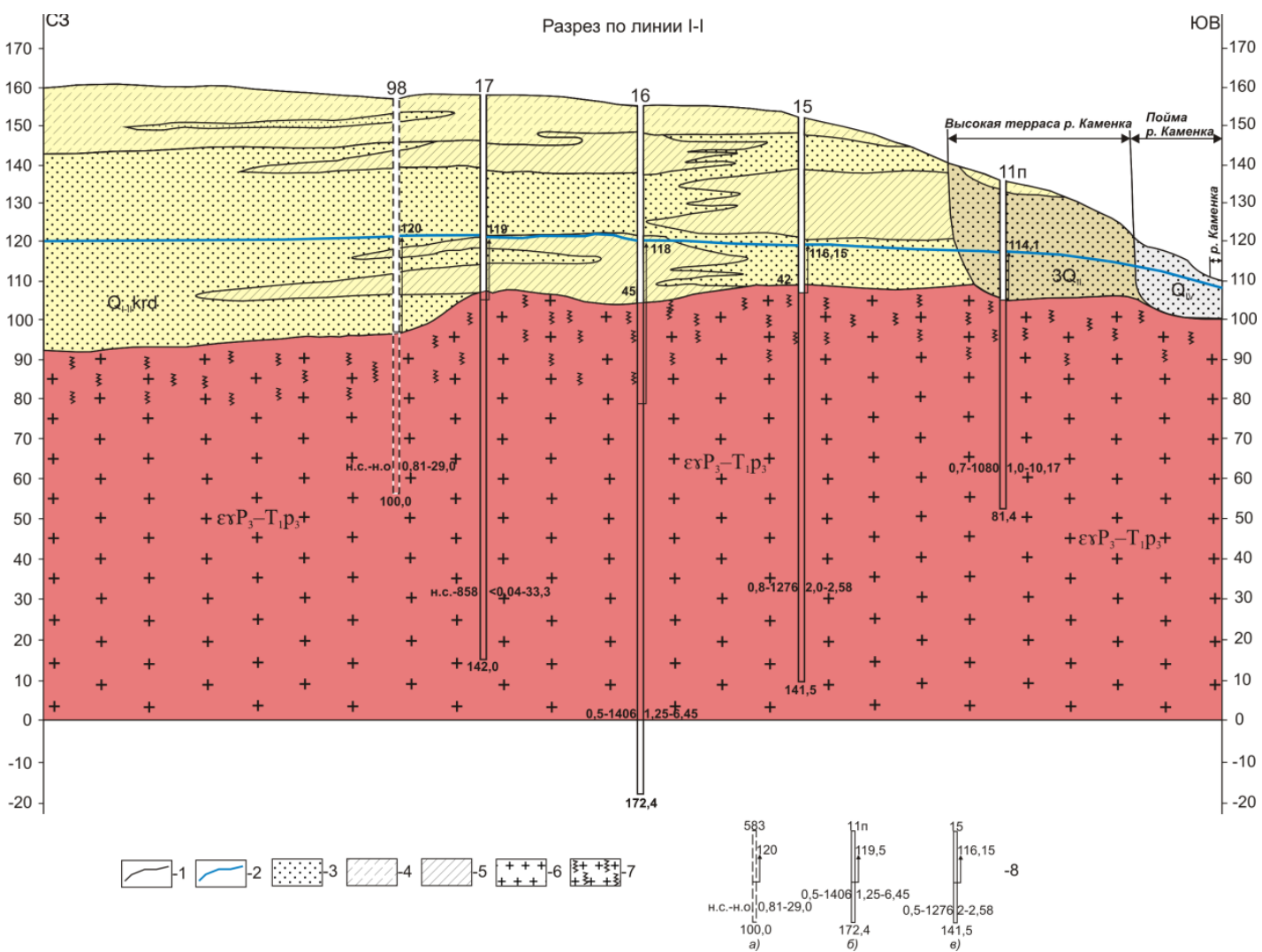

Рис. 3. Гидрогеологический разрез по линии I-I. 1 - границы водоносных горизонтов; 2 - уровень трещинных вод в палеозойских гранитах; 3 - пески; 4 - супеси; 5 - суглинки; 6 - граниты; 7 - кора выветривания по гранитам; 8 - скважины: а) эксплуатационная, б) поисковая, в) разведочная. Цифры: вверху - номер скважины, внизу глубина, м; стрелки соответствуют напору подземных вод, цифра у стрелки - абсолютная отметка уровня,

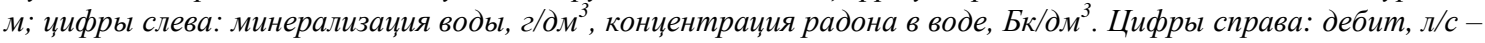
понижение, $м$

Fig. 3. Hydrogeological section along the line I-I. 1 - aquifer boundaries; 2 - level of fractured waters in Paleozoic granites; 3 -sands; 4 -sandy loam; 5 -loams; 6 - granites; 7 - granites weathering crust; 8 -wells: a) exploitation, b) prospecting, $c$ ) exploratory. Numbers at the top: in the top - number of wells on the map, in the bottom-well depth, $m$. Arrows show the groundwater pressure, the number at the arrow - groundwater elevation, m; Numbers on the left: first - TDS, g/l; second-radon concentration in water, Bq/dm ${ }^{3}$. Numbers on the right: flow rate, $l / s-d r a w d o w n$ of water level, $m$ 
Геоморфологическое положение скважин 15 и 16, а также положение уровней подземных вод в скважинах, расположенных по линии от водораздела к дрене, и в р. Каменка дают основание считать, что естественный режим месторождения относится к водораздельному типу. Этот тип естественного режима характеризуется небольшими колебаниями уровня воды и питанием подземных вод за счет талых весенних вод и атмосферных осадков. В условиях Центрального района города Новосибирска, где почти вся площадь поверхности покрыта асфальтом и занята под сооружения и инфильтрация атмосферных осадков осложнена, естественный режим питания подземных вод нарушен.

Как видно из рис. 3, порово-пластовые воды четвертичных отложений, воды зоны региональной трещиноватости и трещинно-жильные воды верхнепалеозойских гранитов находятся в единой области смешения, на которую оказывают влияние процессы подтопления и антропогенного загрязнения. В этой связи в водоносном комплексе верхнепалеозойских гранитов выделяется две гидрогеохимической зоны: верхняя - воды зоны региональной трещиноватости в зоне подтопления в условиях антропогенного воздействия, и нижняя - трещинно-жильные минеральные радоновые воды.

По химическому составу воды первой зоны характеризуются химическими типами от $\mathrm{Cl}-\mathrm{HCO}_{3} \mathrm{Na}-\mathrm{Mg}-\mathrm{Ca}$ до $\mathrm{Cl}-\mathrm{NO}_{3}-\mathrm{HCO}_{3} \mathrm{Na}-\mathrm{Mg}-\mathrm{Ca}$ с величиной общей минерализации до 1712 мг/дм ${ }^{3}$ с содержанием урана до $6,5 \cdot 10^{-4}$ мг/дм ${ }^{3}$ и активностью радона до 1570,0 Бк/дм ${ }^{3}$. Минеральные радоновые воды отличаются преимущественно $\mathrm{HCO}_{3}$ Na-Mg-Ca составом с величиной общей минерализации от 613,4 од 689,9 мг/дм ${ }^{3}$ с содержанием урана от $5,6 \cdot 10^{-3}$ до $6,5 \cdot 10^{-3}$ мг/дм ${ }^{3}$, радия от $2,7 \cdot 10^{-9}$ до $1,8 \cdot 10^{-8}$ мг/дм ${ }^{3}$ и активностью радона 1101-1570 Бк/дм . Для сравнения: минеральные радоновые воды Заельцовского месторождения (рис. 1) характеризуются $\mathrm{HCO}_{3} \mathrm{Na}-\mathrm{Ca}$ составом с величиной общей минерализации от 322,4 до 741,2 мг/дм ${ }^{3}$ с содержанием урана от $1,9 \cdot 10^{-4}$ до $9,8 \cdot 10^{-2} \mathrm{мг} /$ дм $^{3}$, радия от $1,3 \cdot 10^{-9}$ до $1,9 \cdot 10^{-9}$ мг/дм ${ }^{3}$ и активностью радона 185-1801 Бк/дм ${ }^{3}[1]$.

\section{Особенности гидрогеохимии месторождения «Каменское»}

Ранее отмечалась крайне низкая степень изученности геохимических особенностей радоновых вод Новосибирской городской агломерации [25, 26]. Воды месторождения «Каменское» по величине $\mathrm{pH}$ относятся к типам от нейтральных до слабощелочных (рН от 6,8 до $8,0)$, по величине общей минерализации от - ультрапресных до слабосолоноватых (144-1841 мг/дм $\left.{ }^{3}\right)$ (табл. 1). В соответствии с классификацией Н.И. Толстихина по активности радона (163-1570 Бк/дм³) воды относятся к классам от очень слаборадоновых до сильно радоновых. Их химический состав за счет процессов антропогенного влияния имеет весьма пестрый состав (рис. 4, $a$ ).

Анализ коэффициентов ( $\mathrm{Ca} / \mathrm{Na}, \mathrm{Ca} / \mathrm{Mg}, \mathrm{Ca} / \mathrm{Si}$, $\mathrm{Mg} / \mathrm{Si}, \mathrm{Na} / \mathrm{Si}, \mathrm{Si} / \mathrm{Na}, \mathrm{rNa} / \mathrm{rCl}$ и $\mathrm{SO}_{4} / \mathrm{Cl}$ ) позволил разделить имеющиеся гидрогеохимические данные на четыре геохимические группы природных вод: поверх- ностные (группа I); порово-пластовые воды четвертичных отложений в зоне подтопления в условиях антропогенного воздействия (группа II); воды зоны региональной трещиноватости верхнепалеозойских гранитов в зоне подтопления в условиях антропогенного воздействия (группа III) и трещинно-жильные воды верхнепалеозойских гранитов (минеральные радоновые) (группа IV). Дадим краткую характеристику выделенных типов вод по геохимическим разновидностям (группы I-IV) (табл. 1, рис. 4, $a$ ).

Поверхностные воды (группа I) - нейтральные со значениями $\mathrm{pH}(6,9-7,5)$; преимущественно умеренно пресные с величиной общей минерализации от 219,3-340,1 мг/дм ${ }^{3}$ в карьере Каменский до 403,7-593,9 мг/дм ${ }^{3}$ в реке Каменка и средним содержанием кремния 3,4 мг/дм³. Воды затопленного гранитного карьера имеют преимущественно $\mathrm{SO}_{4}-\mathrm{Cl}-\mathrm{HCO}_{3}$ $\mathrm{Ca}-\mathrm{Na}$, а реки Каменка $\mathrm{Cl}-\mathrm{HCO}_{3} \mathrm{Ca}-\mathrm{Na}$ состав. Концентрации $\mathrm{NO}_{3}$ варьируют от следовых до 9,2 \%-экв., что говорит о их значительном загрязнении. В целом поверхностные воды характеризуются средними отношениями $\mathrm{Ca} / \mathrm{Na}=1,5 ; \quad \mathrm{Ca} / \mathrm{Mg}=8,1 ; \quad \mathrm{Ca} / \mathrm{Si}=14,6$; $\mathrm{Mg} / \mathrm{Si}=2,0 ; \quad \mathrm{Na} / \mathrm{Si}=14,6 ; \quad \mathrm{Si} / \mathrm{Na}=0,1 ; \quad \mathrm{rNa} / \mathrm{rCl}=2,1 \quad$ и $\mathrm{SO}_{4} / \mathrm{Cl}=0,7$. При этом воды карьера Каменский имеют более высокое отношение $\mathrm{SO}_{4} / \mathrm{Cl}=0,8$ за счет процессов континентального засоления и окисления сульфидов, тогда как в речных водах оно не превышает $0,3-0,6$. Активность ${ }^{222} \mathrm{Rn}$ в поверхностных водах изменяется в диапазоне от 1 до 11 Бк/дм ${ }^{3}$. Содержание ${ }^{238} \mathrm{U}$ составляет от $4,2 \cdot 10^{-3}$ до $7,6 \cdot 10^{-3} \mathrm{мг} /$ дм $^{3}$.

Порово-пластовые воды четвертичных отложений, в зоне подтопления в условиях антропогенного воздействия (группа II) изучены в трех родниках и в одном колодце (табл. 1). Воды нейтральные $(\mathrm{pH}=7,0-7,4)$, характеризуются величиной общей минерализации от собственно пресных до слабосолоноватых (574,3-1800,3 мг/дм $\left.{ }^{3}\right)$ с содержанием кремния от 6,5 до 7,5 мг/дм ${ }^{3}$. Состав вод варьирует от $\mathrm{Cl}_{-}-\mathrm{HCO}_{3}$ $\mathrm{Na}-\mathrm{Mg}-\mathrm{Ca}$ до $\mathrm{NO}_{3}-\mathrm{Cl}-\mathrm{HCO}_{3} \mathrm{Na}-\mathrm{Ca}$ с концентрацией $\mathrm{NO}_{3}$ от 40 до 400 мг/дм ${ }^{3}$ (от 5,1 до 26,6 \%-экв.). За счет процессов подтопления и антропогенного загрязнения при взаимодействии порово-пластовых вод с преимущественно песчаными отложениями происходит существенное изменение величин основных геохимических коэффициентов. Их средние отношения в терригенно-карбонатных отложениях составляют: $\mathrm{Ca} / \mathrm{Na}=5,5 ; \mathrm{Ca} / \mathrm{Mg}=6,4 ; \mathrm{Ca} / \mathrm{Si}=31,0 ; \mathrm{Mg} / \mathrm{Si}=3,1$; $\mathrm{Na} / \mathrm{Si}=5,2 ; \mathrm{Si} / \mathrm{Na}=0,3 ; \mathrm{rNa} / \mathrm{rCl}=0,5$ и $\mathrm{SO}_{4} / \mathrm{Cl}=0,7$. Доминируют кальциевые алюмосиликатные минералы. Спектр средних содержаний микрокомпонентов (табл. 2) имеет следующий вид (мг/дм $\left.{ }^{3}\right): \mathrm{Sr}_{5,3}>\mathrm{Ba}_{0,46}>\mathrm{Ti}_{0,024}>$ $\mathrm{Zr}_{0,017}>\mathrm{Mn}_{0,016}>\mathrm{Co}_{0,007}>\mathrm{Cr}_{0,007}>\mathrm{U}_{0,003}>\mathrm{Ni}_{0,001}>\mathrm{Cu}_{0,0007}>$ $\mathrm{Mo}_{0,0001}>\mathrm{Ag}_{0,0001}>\mathrm{Zn}_{0,000008}$. Активность ${ }^{222} \mathrm{Rn}$ в водах родников изменяется от 167 до 197 Бк/дм ${ }^{3}$ и составляет 326 Бк/дм ${ }^{3}$ в колодце. Концентрации природных радионуклидов в водах варьируют $\left(\right.$ мг/дм $\left.{ }^{3}\right):{ }^{238} \mathrm{U}$ $\left(4,5 \cdot 10^{-4}-7,8 \cdot 10^{-3}\right),{ }^{226} \mathrm{Ra}\left(1,3 \cdot 10^{-4}-7,8 \cdot 10^{-3}\right)$.

Ниже залегающие воды зоны региональной трещчиноватости верхнепалеозойских гранитов, в зоне подтопления в условиях антропогенного воздействия (группа III) по значениям $\mathrm{pH}(6,8-8,0)$ относятся к ти- 
пу от нейтральных до слабощелочных, при доминировании первых. Величина общей минерализации составляет от 955,5 до 1712,0 мг/дм ${ }^{3}$, что соответствует собственно пресным и слабосолоноватым водам. Содержания кремния растут местами до 11,2 мг/дм ${ }^{3}$, при среднем значении 8,3 мг/дм³ ${ }^{3}$. Загрязнение нитратионом составляет от 63 до 300 мг/дм ${ }^{3}$, его доля в анионном составе изменяется от 7,8 до 24,2 \%-экв. Концентрации хлоридов варьируют в диапазоне от 78 до 220 мг/дм ${ }^{3}$, увеличиваясь до 16,0-27,3 \%-экв, сульфат-иона от 36 до 102 мг/дм ${ }^{3}$, составляя до 5,5-12,7 \%-экв. За счет антропогенного загрязнения воды зоны региональной трещиноватости имеют пестрый состав, который варьирует от $\mathrm{SO}_{4}-\mathrm{Cl}-\mathrm{HCO}_{3}$ $\mathrm{Na}-\mathrm{Mg}-\mathrm{Ca}$ до $\mathrm{Cl}_{-} \mathrm{NO}_{3}-\mathrm{HCO}_{3} \mathrm{Na}-\mathrm{Mg}-\mathrm{Ca}$ (табл. 1). Процессы взаимодействия вод с вмещающими гранитами характеризуются средними отношениями основных геохимических коэффициентов, которые равны: $\mathrm{Ca} / \mathrm{Na}-6,8 ; \mathrm{Ca} / \mathrm{Mg}-4,4 ; \mathrm{Ca} / \mathrm{Si}-29,6 ; \mathrm{Mg} / \mathrm{Si}-7,0$; $\mathrm{Na} / \mathrm{Si}-6,2 ; \mathrm{Si} / \mathrm{Na}-0,2 ; \mathrm{rNa} / \mathrm{rCl}-0,5$ и $\mathrm{SO}_{4} / \mathrm{Cl}-0,6$ Спектр средних концентраций микрокомпонентов в водах имеет следующую последовательность (мг/дм $\left.{ }^{3}\right)$ : $\mathrm{Sr}_{0,37}>\mathrm{Mn}_{0,25}>\mathrm{Ba}_{0,24}>\mathrm{Ti}_{0,036}>\mathrm{Ni}_{0,004}>\mathrm{Mo}_{0,003}>\mathrm{Co}_{0,002}>\mathrm{Cu}_{0,002}>$ $\mathrm{Be}_{0,001}>\mathrm{U}_{0,0003}$. Активность ${ }^{222} \mathrm{Rn}$ в водах изменяется в диапазоне от 618 до 1124 Бк/дм ${ }^{3}$. Содержание ${ }^{238} \mathrm{U}$ coставляет $1,3 \cdot 10^{-4}-6,5 \cdot 10^{-4} \mathrm{M} / \mathrm{дм}^{3}, \mathrm{a}^{226} \mathrm{Ra}$ от $1,3 \cdot 10^{-9}$ до $7,2 \cdot 10^{-9} \mathrm{мг} /$ дм $^{3}$.

Трещчинно-жильные минеральные радоновые воды верхнепалеозойских гранитов (группа IV) - преимущественно нейтральные со значениями $\mathrm{pH}(6,9-7,8)$; собственно пресные с величиной общей минерализации от 613,4 до 690,0 мг/дм ${ }^{3}$. Воды не затронуты процессами подтопления и антропогенного загрязнения и относятся преимущественно к $\mathrm{HCO}_{3} \mathrm{Na}-\mathrm{Mg}$-Са типу с высоким содержанием кремния от 10,3 до 13,6 мг/дм³ при среднем значении 11,7 мг/дм ${ }^{3}$. Взаимодействие трещинно-жильных вод с гранитами при окислении сульфидов характеризуется снижением средних отношений $\mathrm{Ca} / \mathrm{Na}$ до 3,$4 ; \mathrm{Ca} / \mathrm{Si}$ до 9,$1 ; \mathrm{Mg} / \mathrm{Si}$ до 1,7 ; $\mathrm{Na} / \mathrm{Si}$ до 2,8 и ростом $\mathrm{Ca} / \mathrm{Mg}$ до 6,$8 ; \mathrm{Si} / \mathrm{Na}$ до 0,4 $\mathrm{rNa} / \mathrm{rCl}$ до 3,5 и $\mathrm{SO}_{4} / \mathrm{Cl}$ до 1,0 соответственно. Спектр средних содержаний микрокомпонентов в минеральных радоновых водах образует следующий ряд (мг/дм³): $\mathrm{Sr}_{1,6}>\mathrm{Mn}_{0,83}>\mathrm{Ba}_{0,064}>\mathrm{Ti}_{0,045}>\mathrm{Ni}_{0,016}>\mathrm{U}_{0,006}>\mathrm{Mo}_{0,004}>\mathrm{Cu}_{0,003}>$ $\mathrm{Zn}_{0,003}$. Средние содержания микрокомпонентов в верхнепалеозойских гранитах составляют (г/т): $\mathrm{Sr}_{1152}>\mathrm{Ba}_{971}>\mathrm{Cr}_{194}>\mathrm{Zr}_{167}>\mathrm{Zn}_{49}>\mathrm{Ni}_{35}>\mathrm{Cu}_{18}>\mathrm{Co}_{8}>\mathrm{U}_{4}>\mathrm{Mo}_{3}>$ $\mathrm{Be}_{2}>\mathrm{Ag}_{0,04}$. При этом следует отметить, что спектр распределения микрокомпонентов в радоновых водах в целом имеет унаследованный характер при сравнении с вмещающими гранитами (совпадение основных пиков). По сравнению с изученным ранее Заельцовским месторождением минеральных радоновых вод, расположенным северо-западнее от района исследований, концентрации ряда микрокомпонентов в этих водах значительно выше и составляют (мг/дм $\left.{ }^{3}\right): \mathrm{Sr}$ до $4,7, \mathrm{Mn}$ до 1,3 , Мо до $3,1 \cdot 10^{-2}$ и т. д. [2, 35, 36]. Активность ${ }^{222} \mathrm{Rn}$ в минеральных водах месторождения «Каменское» варьирует в интервале от 1101 до 1570 Бк/дм ${ }^{3}$ Содержание ${ }^{238} \mathrm{U}$ составляет от $5,6 \cdot 10^{-3}$ до $6,5 \cdot 10^{-3}$ мг/дм ${ }^{3}$ и ${ }^{226} \mathrm{Ra}$ от $2,7 \cdot 10^{-9}$ до $1,8 \cdot 10^{-8}$ мг/дм ${ }^{3}$.
В радоновых водах месторождения «Каменское» был изучен состав спонтанного и водорастворенного газа (ВРГ), а также величина общей газонасыщенности вод, которая изменяется от 130 до $6400 \mathrm{~cm}^{3} / \mathrm{m}^{3}$. Среди газов в водах месторождения установлены кислород, углекислый газ и азот. В спонтанно выделяющемся газе содержание кислорода составляет 0,66 об. \%, $\mathrm{CO}_{2}$ варьирует от 1,78 до 2,74 об. \%, азота 96,69-98,16 об. \%. В ВРГ средние содержания $\mathrm{O}_{2}-$ 19 об. \%, $\mathrm{CO}_{2}-2$ об. \%, $\mathrm{N}_{2}-79$ об. \% (рис. 4, б), такой состав газов отвечает гидрогеохимическому типу кислородно-азотных вод.

\section{Интенсивность водной миграции}

и источники элементов в радоновых водах

Среди геологических факторов минералогические особенности водовмещающих гранитов Новосибирского массива выступают основными при протекании процессов формирования химического состава радоновых вод. Рудными минералами - источниками поступления $\mathrm{Fe}, \mathrm{Ti}, \mathrm{V}, \mathrm{Zn}, \mathrm{Mo}, \mathrm{Sn}, \mathrm{Ag}, \mathrm{Pb}, \mathrm{Be}, \mathrm{Li}, \mathrm{Zr}, \mathrm{Y}$, $\mathrm{Yb}, \mathrm{REE}, \mathrm{Nb}$ в воды, являются магнетит $\left(\mathrm{FeFe}_{2} \mathrm{O}_{4}\right)$, ильменит $\left(\mathrm{FeTiO}_{3}\right)$, молибденит $\left(\mathrm{MoS}_{2}\right)$, касситерит $(\mathrm{SnO})$, циркон $\left(\mathrm{Zr}\left[\mathrm{SiO}_{4}\right]\right)$, монацит ((Ce,La,Nd,Th)[PO $\left.\left.\mathrm{PO}_{4}\right]\right)$, ксенотим (Y[PO $\left.\left.{ }_{4}\right]\right)$ и другие. А.И. Перельманом [38] был предложен метод оценки водной миграции химических элементов в зоне гипергенеза по коэффициенту $\left(\mathrm{Kx}_{1}\right)$, который определяется как отношение содержания химического элемента в минеральном остатке воды к его содержанию в водовмещающих породах или кларку литосферы. Этот коэффициент отражает интенсивность водной миграции, определяемую свойствами самого элемента, а также степень его концентрирования или рассеяния в природных водах. Для расчетов были использованы кларки литосферы [39].

Усредненные значения коэффициентов водной миграции химических элементов в трещинножильных радоновых водах верхнепалеозойских гранитов выстроились следующим образом: очень сильная интенсивность $\mathrm{Ra}_{11,91}>$ сильная $\mathrm{Sr}_{9,48}>\mathrm{Mo}_{2,03}>\mathrm{U}_{1,45}>$ средняя $\mathrm{Mn}_{0,75}>\mathrm{Ba}_{0,47}>\mathrm{Be}_{0,43}>\mathrm{Ni}_{0,16}>$ слабая (инертная) $>$ $\mathrm{Cu}_{0,068}>\mathrm{Zn}_{0,02}>\mathrm{Ti}_{0,011}>\mathrm{Fe}_{0,002}$.

\section{Формы миграции химических элементов}

Выявленные выше геохимические особенности и физико-химические параметры определили формы нахождения элементов в радоновых водах. Так, определяющим фактором концентрирования элементов в растворе являются вмещающие горные породы, в первую очередь граниты. Существенную роль играет антропогенное влияние и как следствие изменение основных геохимических коэффициентов в водах зоны подтопления четвертичных отложений и верхнепалеозойских гранитов. Так, с ростом минерализации радоновых вод отмечается снижение доли свободных ионов $\mathrm{Mg}^{2+}, \mathrm{Ca}^{2+}, \mathrm{Na}^{+}, \mathrm{Sr}^{2+}$ и $\mathrm{Ba}^{2+}$. Например, содержания бария (2 класс опасности) в некоторых пробах превышают значения ПДК в 2-6 раз, что объясняется его высокими концентрациями во вмещающих гранитах до 971,3 г/т (табл. 2). 
Таблица 1. Химические анализы типовых проб месторождения радоновых вод «Каменское», г. Новосибирск (мг/дм³)

Table 1. Chemical analysis of samples of the radon water deposit «Kamenskoe», Novosibirsk $\left(\mathrm{mg} / \mathrm{dm}^{3}\right)$

\begin{tabular}{|c|c|c|c|c|c|c|c|c|c|c|c|c|c|c|c|c|c|}
\hline \multirow{2}{*}{$\begin{array}{l}\text { № скв, место } \\
\text { отбора } \\
\text { Well no., sam- } \\
\text { pling location } \\
\end{array}$} & \multirow{2}{*}{\begin{tabular}{|c|c} 
Интервал \\
откачки, м \\
Pumping \\
interval, m
\end{tabular}} & \multirow{2}{*}{$\mathrm{pH}$} & $\mathrm{M}^{* *}$ & $\mathrm{HCO}_{3}^{-}$ & $\mathrm{NO}_{3}^{-}$ & $\mathrm{SO}_{4}{ }^{2-}$ & $\mathrm{Cl}^{-}$ & $\mathrm{Ca}^{+}$ & $\mathrm{Mg}^{2+}$ & $\mathrm{Na}^{3+}$ & $\mathrm{NH}_{4}^{+}$ & $\mathrm{Fe}_{\text {обш }}$ & $\mathrm{Si}$ & ${ }^{222} \mathrm{Rn}$ & ${ }^{238} \mathrm{U}$ & ${ }^{226} \mathrm{Ra}$ & \multirow{2}{*}{$\begin{array}{c}\text { Формула } \\
\text { M.Г. Курлова } \\
\text { M.G. Kurlov } \\
\text { formula } \\
\end{array}$} \\
\hline & & & \multicolumn{11}{|c|}{$\begin{array}{l}\mathrm{M \Gamma} / \mathrm{dm}^{3} \\
\mathrm{mg} / \mathrm{dm}^{3} \\
\end{array}$} & $\begin{array}{l}\text { Бк/дм } \\
\mathrm{Bq} / \mathrm{dm}^{3}\end{array}$ & \multicolumn{2}{|c|}{$\begin{array}{r}\mathrm{M \Gamma} / \mathrm{Am}^{3} \\
\mathrm{mg} / \mathrm{dm}^{3} \\
\end{array}$} & \\
\hline \multicolumn{18}{|c|}{ Поверхностные воды (группа I)/Surface waters (group I) } \\
\hline \begin{tabular}{c|} 
p. Каменка \\
Kamenka river
\end{tabular} & $*$ & 6,8 & 438,3 & 244 & 31 & 11 & 31 & 48 & 4 & 66 & 0 & 3,3 & 2,8 & 7 & $4,6 \cdot 10^{-3}$ & - & $\begin{array}{c}\mathrm{Cl}-\mathrm{HCO}_{3} \\
\mathrm{Ca}-\mathrm{Na}\end{array}$ \\
\hline $\begin{array}{c}\text { p. Каменка } \\
\text { Kamenka river }\end{array}$ & $*$ & 6,9 & 403,7 & 232 & 16 & 21 & 31 & 66 & 13 & 23 & 1 & 0,7 & 3,7 & 9 & $4,8 \cdot 10^{-3}$ & - & $\begin{array}{c}\mathrm{Cl}-\mathrm{HCO}_{3} \\
\mathrm{Na}-\mathrm{Mg}-\mathrm{Ca} \\
\end{array}$ \\
\hline \begin{tabular}{c|} 
Карьер \\
Каменский \\
Kamensky \\
open pit \\
\end{tabular} & $*$ & 7,2 & 311,5 & 146 & 9 & 28 & 39 & 35 & 3 & 51 & 0 & 0,5 & 1,9 & 1 & $7,6 \cdot 10^{-3}$ & - & $\begin{array}{c}\mathrm{SO}_{4}-\mathrm{Cl}-\mathrm{HCO}_{3} \\
\mathrm{Ca}-\mathrm{Na}\end{array}$ \\
\hline $\begin{array}{l}\text { Карьер } \\
\text { Каменский } \\
\text { Kamensky } \\
\text { open pit }\end{array}$ & * & 6,9 & 340,1 & 183 & 8 & 24 & 36 & 59 & 11 & 19 & 0 & 0,1 & 4,2 & 3 & $7,6 \cdot 10^{-3}$ & - & $\begin{array}{c}\mathrm{SO}_{4}-\mathrm{Cl}-\mathrm{HCO}_{3} \\
\mathrm{Na}-\mathrm{Mg}-\mathrm{Ca}\end{array}$ \\
\hline $\begin{array}{c}\text { Карьер } \\
\text { Каменский } \\
\text { Kamensky } \\
\text { open pit } \\
\end{array}$ & $*$ & 7,5 & 219,3 & 104 & 0 & 18 & 20 & 27 & 3 & 35 & 0 & 0,3 & 3,3 & 3 & $6,4 \cdot 10^{-3}$ & - & $\begin{array}{c}\mathrm{SO}_{4}-\mathrm{Cl}-\mathrm{HCO}_{3} \\
\mathrm{Ca}-\mathrm{Na}\end{array}$ \\
\hline $\begin{array}{c}\text { p. Каменка } \\
\text { Kamenka river }\end{array}$ & * & 6,9 & 593,9 & 370 & 0 & 26 & 40 & 56 & 10 & 72 & 18 & 1,9 & 4,7 & 11 & \begin{tabular}{|l|l|l|l} 
& $-2 \cdot 10^{-3}$ \\
\end{tabular} & - & $\begin{array}{c}\mathrm{Cl}_{-}-\mathrm{HCO}_{3} \\
\mathrm{Mg}-\mathrm{NH}_{4}-\mathrm{Ca}-\mathrm{Na} \\
\end{array}$ \\
\hline \multicolumn{18}{|c|}{$\begin{array}{l}\text { Порово-пластовые воды четвертичных отложений, в зоне подтопления в условиях антропогенного воздействия (группа II) } \\
\text { Pore-stratal waters of Quaternary sediments, in the flooded zone under anthropogenic impact (group II) }\end{array}$} \\
\hline \begin{tabular}{c|} 
Родник 3 \\
Spring 3 \\
\end{tabular} & $*$ & 7,0 & 1800,3 & 495 & 400 & 111 & 282 & 414 & 5 & 93 & 0 & 0,3 & 7,5 & 167 & $7,8 \cdot 10^{-3}$ & - & $\begin{array}{c}\mathrm{NO}_{3}-\mathrm{Cl}-\mathrm{HCO}_{3} \\
\mathrm{Na}-\mathrm{Ca} \\
\end{array}$ \\
\hline $\begin{array}{c}\text { Родник } 2 \\
\text { Spring } 2 \\
\end{array}$ & $*$ & 7,4 & 987,0 & 409 & 100 & 95 & 121 & 237 & 23 & 2 & 0 & - & 7,5 & 197 & $4,5 \cdot 10^{-4}$ & $1,3 \cdot 10^{-9}$ & $\begin{array}{c}\mathrm{NO}_{3}-\mathrm{SO}_{4} \\
\mathrm{Cl}-\mathrm{HCO}_{3} \\
\mathrm{Mg}-\mathrm{Ca} \\
\end{array}$ \\
\hline $\begin{array}{c}\text { Родник } 4 \\
\text { Spring } 4 \\
\end{array}$ & $*$ & 7,4 & 574,4 & 282 & 100 & 26 & 26 & 108 & 20 & 12 & 0 & 0,4 & 6,5 & 167 & $7,8 \cdot 10^{-4}$ & - & $\begin{array}{c}\mathrm{NO}_{3}-\mathrm{HCO}_{3} \\
\mathrm{Mg}-\mathrm{Ca}\end{array}$ \\
\hline $\begin{array}{c}\text { Колодец } 102 \\
\text { Well } 102\end{array}$ & $2-2,2$ & 7,4 & 946,0 & 495 & 40 & 55 & 113 & 153 & 42 & 48 & 0 & 0,0 & 7,5 & 326 & $9,8 \cdot 10^{-4}$ & $1,5 \cdot 10^{-8}$ & $\begin{array}{c}\mathrm{Cl}-\mathrm{HCO}_{3} \\
\mathrm{Na}-\mathrm{Mg}-\mathrm{Ca} \\
\end{array}$ \\
\hline \multicolumn{18}{|c|}{$\begin{array}{c}\text { Воды зоны региональной трещиноватости верхнепалеозойских гранитов, в зоне подтопления в условиях антропогенного воздействия (группа III) } \\
\text { Regional fracture zone waters of the Upper Paleozoic granites in the flooding zone under anthropogenic impact (group III) }\end{array}$} \\
\hline 15 & $47-48$ & 6,9 & 1529 & 625 & 300 & 98 & 120 & 269 & 57 & 58 & 1,2 & 0,3 & 7,9 & 618 & $2,1 \cdot 10^{-4}$ & $1,3 \cdot 10^{-9}$ & $\begin{array}{c}\mathrm{Cl}-\mathrm{NO}_{3}-\mathrm{HCO}_{3} \\
\mathrm{Na}-\mathrm{Mg}-\mathrm{Ca} \\
\end{array}$ \\
\hline 15 & 50-54 & 6,9 & 1712 & 683 & 280 & 102 & 220 & 311 & 96 & 17 & 0,4 & 2,6 & 8,9 & 814 & $3,9 \cdot 10^{-4}$ & $2,6 \cdot 10^{-9}$ & $\begin{array}{c}\mathrm{NO}_{3}-\mathrm{Cl}-\mathrm{HCO}_{3} \\
\mathrm{Mg}-\mathrm{Ca}\end{array}$ \\
\hline 15 & $62-64$ & 6,9 & 1298 & 580 & 190 & 83 & 118 & 230 & 53 & 43 & 0,7 & 0,5 & 9,3 & 1110 & $4,1 \cdot 10^{-4}$ & $2,2 \cdot 10^{-9}$ & $\begin{array}{c}\mathrm{NO}_{3}-\mathrm{Cl}-\mathrm{HCO}_{3} \\
\mathrm{Na}-\mathrm{Mg}-\mathrm{Ca} \\
\end{array}$ \\
\hline 15 & $72-76$ & 6,8 & 1310 & 586 & 170 & 94 & 128 & 247 & 53 & 28 & 3,6 & - & 11,2 & 994 & $3,6 \cdot 10^{-4}$ & $3,6 \cdot 10^{-9}$ & $\begin{array}{c}\mathrm{SO}_{4}-\mathrm{NO}_{3}-\mathrm{Cl}-\mathrm{HCO}_{3} \\
\mathrm{Mg}-\mathrm{Ca}\end{array}$ \\
\hline 15 & $81-86$ & 8,0 & 1004 & 483 & 124 & 36 & 78 & 186 & 35 & 38 & 0 & 0,2 & 7,0 & 1124 & $6,5 \cdot 10^{-4}$ & $7,2 \cdot 10^{-9}$ & $\begin{array}{c}\mathrm{NO}_{3}-\mathrm{Cl}-\mathrm{HCO}_{3} \\
\mathrm{Na}-\mathrm{Mg}-\mathrm{Ca} \\
\end{array}$ \\
\hline 15 & $87-96$ & 7,0 & 1294 & 610 & 150 & 90 & 117 & 242 & 51 & 34 & 0 & 0,4 & 8,4 & - & $3,6 \cdot 10^{-4}$ & $4,5 \cdot 10^{-9}$ & $\begin{array}{c}\mathrm{SO}_{4}-\mathrm{NO}_{3}-\mathrm{Cl}-\mathrm{HCO}_{3} \\
\mathrm{Mg}-\mathrm{Ca} \\
\end{array}$ \\
\hline 15 & 110-117 & 7,2 & 1122 & 488 & 120 & 90 & 110 & 207 & 48 & 33 & 1 & 0,5 & 8,4 & 987 & $3,1 \cdot 10^{-4}$ & - & $\begin{array}{c}\mathrm{SO}_{4}-\mathrm{NO}_{3}-\mathrm{Cl}-\mathrm{HCO}_{3} \\
\mathrm{Mg}-\mathrm{Ca} \\
\end{array}$ \\
\hline $11 \Pi / p$ & $63,5-64,7$ & 6,9 & 956 & 427 & 63 & 82 & 130 & 151 & 39 & 56 & 0 & 7,5 & 2,8 & 1123 & $1,3 \cdot 10^{-4}$ & $5,3 \cdot 10^{-9}$ & $\begin{array}{c}\mathrm{SO}_{4}-\mathrm{Cl}-\mathrm{HCO}_{3} \\
\mathrm{Na}-\mathrm{Mg}-\mathrm{Ca} \\
\end{array}$ \\
\hline 11ח/p & $75-76$ & 6,9 & 1118 & 589 & 80 & 45 & 118 & 179 & 44 & 60 & 3 & 0,3 & 10,3 & 1076 & $2,7 \cdot 10^{-4}$ & - & \begin{tabular}{c|c|c|}
$\mathrm{Cl}-\mathrm{HCO}_{3}$ \\
$\mathrm{Na}-\mathrm{Mg}-\mathrm{Ca}$ \\
\end{tabular} \\
\hline \multicolumn{18}{|c|}{$\begin{array}{c}\text { Трещинно-жильные воды верхнепалеозойских гранитов (минеральные радоновые) (группа IV) } \\
\text { Fissure-vein waters of the Upper Paleozoic granites (mineral radon) (group IV) }\end{array}$} \\
\hline $4 \Pi / p$ & 73-74 & 6,9 & 654,4 & 478 & 0 & 12 & 8 & 101 & 23,1 & 31 & 0 & 1,3 & 11,2 & 1187 & $6,5 \cdot 10^{-3}$ & $7,9 \cdot 10^{-9}$ & $\begin{array}{c}\mathrm{HCO}_{3} \\
\mathrm{Na}-\mathrm{Mg}-\mathrm{Ca}\end{array}$ \\
\hline 16 & $86,5-87,5$ & 7,0 & 676,0 & 485 & 0 & 6 & 20 & 107 & 21 & 37 & 0 & - & 10,3 & 1101 & $6,5 \cdot 10^{-3}$ & $8,2 \cdot 10^{-9}$ & $\begin{array}{c}\mathrm{HCO}_{3} \\
\mathrm{Na}-\mathrm{Mg}-\mathrm{Ca} \\
\end{array}$ \\
\hline 16 & $91-92$ & 7,8 & 689,9 & 495 & 0 & 13 & 14 & 105 & 22 & 30 & 6,0 & 4,9 & 10,3 & 1213 & $6,5 \cdot 10^{-3}$ & $1,8 \cdot 10^{-8}$ & $\begin{array}{c}\mathrm{HCO}_{3} \\
\mathrm{Na}-\mathrm{Mg}-\mathrm{Ca} \\
\end{array}$ \\
\hline 16 & 104-108 & 6,9 & 613,4 & 400 & 0 & 30 & 24 & 112 & 7 & 37 & 0,4 & 3,0 & 13,1 & 1305 & $6,5 \cdot 10^{-3}$ & - & $\begin{array}{l}\mathrm{HCO}_{3} \\
\mathrm{Na}-\mathrm{Ca}\end{array}$ \\
\hline 16 & $127-128$ & 6,9 & 629,0 & 453 & 0 & 14 & 12 & 99 & 25 & 24 & 0,7 & 1,3 & 13,6 & 1216 & $5,6 \cdot 10^{-3}$ & $2,7 \cdot 10^{-9}$ & $\begin{array}{c}\mathrm{HCO}_{3} \\
\mathrm{Na}-\mathrm{Mg}-\mathrm{Ca}\end{array}$ \\
\hline
\end{tabular}

Примечание: «-»-нет данных; *-на дневной поверхности; ** - величина общей минерализации.

Note: «-»-no data; * on the day surface; ** - the value of the total mineralization of radon waters, $\mathrm{mg} / \mathrm{dm}^{3}$. 
Таблица 2. Микрокомпонентный состав типовых проб месторождения радоновых вод «Каменское», г. Новосибирск

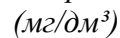

Table 2. Microcomponent composition of typical samples of the «Kamenskoe» radon water deposit, Novosibirsk $\left(\mathrm{mg} / \mathrm{dm}^{3}\right)$

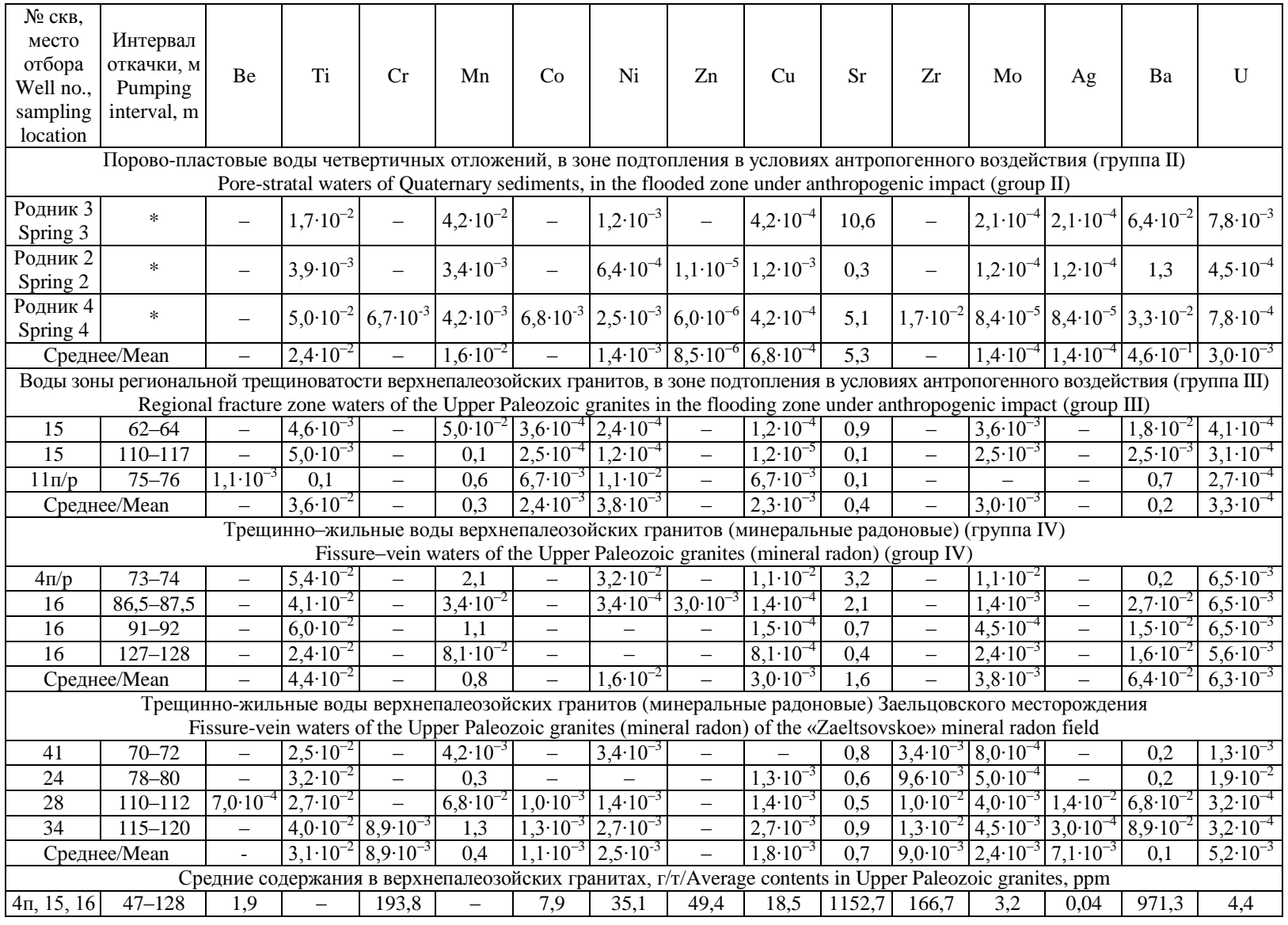

Примечание: см. табл. 1/Note: see Table 1.

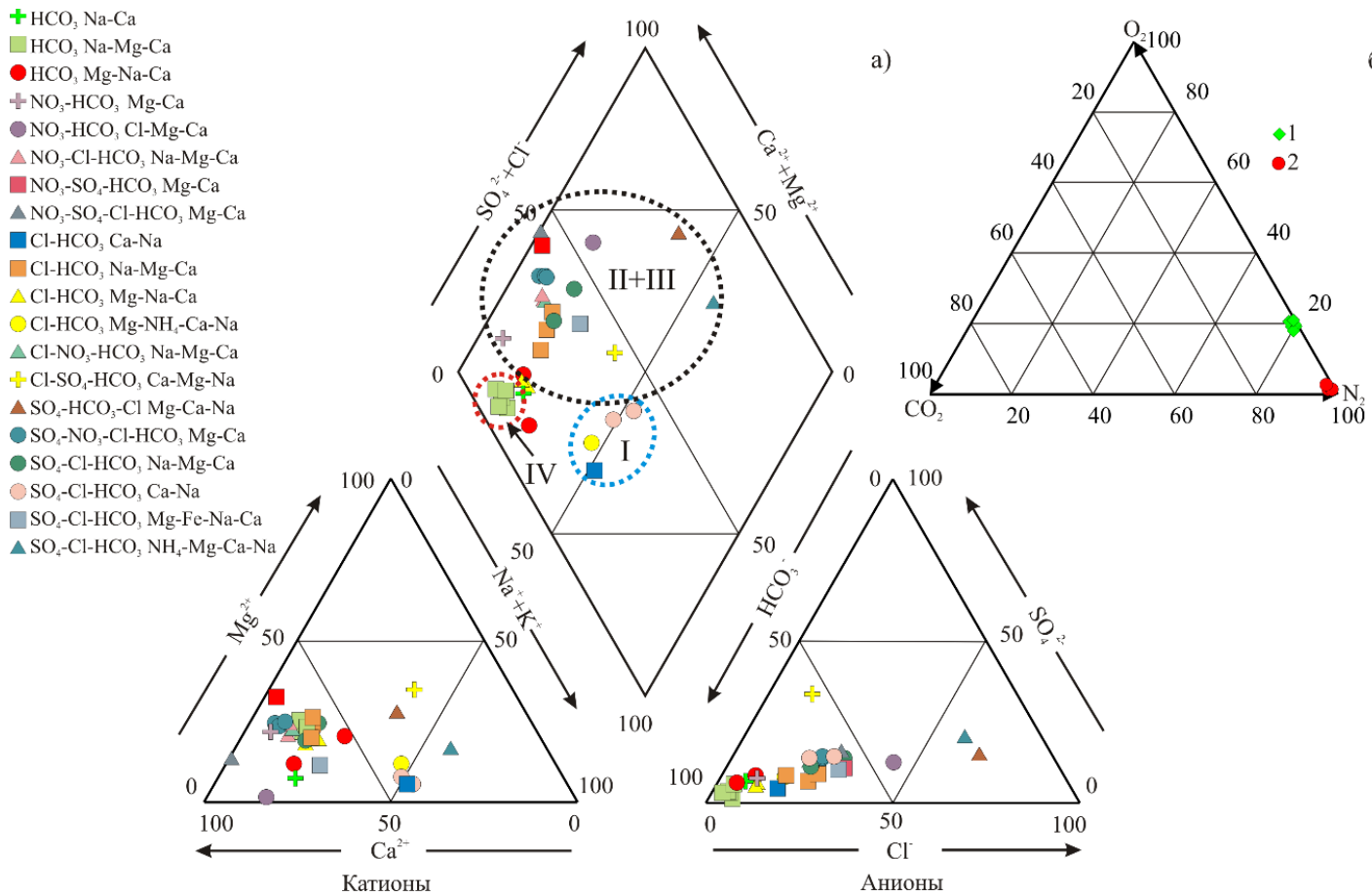

Pис. 4. Диаграмма Пайпера состава радоновых вод (а) и водорастворенных газов (б) месторождения «Каменское». Газы: 1 - водорастворенные; 2 - спонтанные

Fig. 4. Piper diagram of the composition of radon waters (a) and water-dissolved gases of the «Kamenskoe» field. Gases: 1 -water-dissolved; 2 - spontaneous 
Его основными формами миграции являются $\mathrm{Ba}^{2+}$ в 92,91-100\% случаев, $\mathrm{BaHCO}_{3}^{+}-2,70-3,85 \%$ и $\mathrm{BaSO}_{4}{ }^{0}-0,35-3,96 \%$ от общего содержания. Формы бериллия (1 класс опасности) представлены в виде нейтрального гидроксокомплекса $\mathrm{Be}(\mathrm{OH})_{2}(98,8$ \%), а его концентрации, нередко превышающие ПДК в 5,5 раз, также обязаны гранитам (1,9 г/т). В радоновых водах формы $\mathrm{Fe}(\mathrm{II})$ представлены в виде соединений $\mathrm{Fe}^{2+}, \mathrm{FeHCO}_{3}{ }^{+}, \mathrm{FeCO}_{3}{ }^{0}$. $\mathrm{Fe}(\mathrm{III})$ в форме положительно заряженных гидроксокомплексов $\mathrm{Fe}(\mathrm{OH})_{2}{ }^{+}$и нейтральных $\mathrm{Fe}(\mathrm{OH})_{3}{ }^{0}$. Его нахождение в растворе обязано наличию сульфидной минерализации в гранитах, а также присутствию органических веществ. Марганец, как и железо, принадлежит к числу элементов, окисленные формы которого гораздо менее растворимы, чем восстановленные. Концентрации марганца в ряде проб превышают ПДК в 21 раз. Среди его форм миграции доминирует простой катион $\mathrm{Mn}^{2+}$ (43,71-99,99\%), остальные формы представлены $\mathrm{MnHCO}_{3}{ }^{+}(9,89-28,27 \%), \mathrm{MnCO}_{3}{ }^{0}(0,01-37,39)$, еще в меньшей степени $\mathrm{MnSO}_{4}{ }^{0}(0,20-2,25 \%), \mathrm{MnCl}^{+}$ $(0,04-1,12 \%)$ и $\mathrm{MnOH}^{+}(0,01-0,05 \%)$. Химические формы миграции тяжелых металлов (никеля и меди) представлены в виде свободных катионов $\left(\mathrm{Ni}^{2+}, \mathrm{Cu}^{2+}\right)$, гидрокарбонатных $\left(\mathrm{NiHCO}_{3}^{-}, \mathrm{CuHCO}_{3}^{-}\right)$и карбонатных $\left(\mathrm{NiCO}_{3}{ }^{0}, \mathrm{CuCO}_{3}{ }^{0}\right)$ комплексов. Медь также мигрирует в нейтральной гидроксидной форме $\mathrm{Cu}(\mathrm{OH})_{2}{ }^{0}$.

\section{Степень насыщения радоновых вод}

к ряду минеральных фаз

Выявленные особенности геохимических типов вод, долевого распределения форм и коэффициентов водной миграции химических элементов позволили оценить направленность процессов аутигенного минералообразования в системе вода-порода (рис. 5) Так, маломинерализованные поверхностные воды (группа I) пересыщены относительно ферригидрита $\left(\mathrm{Fe}_{10} \mathrm{O}_{14}(\mathrm{OH})_{2}\right)$, равновесны к гриналиту $\left(\left(\mathrm{Fe}^{2+}, \mathrm{Fe}^{3+}\right)_{2-}\right.$ $\left.{ }_{3} \mathrm{Si}_{2} \mathrm{O}_{5}(\mathrm{OH})_{4}\right)$ и сидериту, достигают околоравновесного состояния с кальцитом, и не насыщены доломитом, магнезитом, ангидритом, сепиолитом $\left(\mathrm{Mg}_{4} \mathrm{Si}_{6} \mathrm{O}_{15}(\mathrm{OH})_{2} \cdot 6 \mathrm{H}_{2} \mathrm{O}\right)$ и тальком $\left(\mathrm{Mg}_{3} \mathrm{Si}_{4} \mathrm{O}_{10}(\mathrm{OH})_{2}\right)$. Порово-пластовые воды четвертичных отложений, в зоне подтопления в условиях антропогенного воздействия (группа II) пересыщены относительно кальцита и доломита. Они находятся в околоравновесном состоянии с магнезитом и гриналитом и недонасыщены относительно родохрозита, ангидрита, сепиолита и талька. Воды зоны региональной трещиноватости верхнепалеозойских гранитов, в зоне подтопления в условиях антропогенного воздействия (группа III) также пересыщены относительно ферригидрита, кальцита и доломита. Наблюдается пересыщение отдельных проб сидеритом и тальком. Воды далеки от равновесия с ангидритом, гриналитом, сепиолитом и тальком. Немногочисленные пробы минеральных радоновых вод (группа IV) закономерно пересыщены относительно ферригидрита, кальцита, сидерита и родохрозита. Не наблюдается их равновесия с магнезитом, ангидритом, сепиолитом и тальком. В целом состав равновесных минералов усложняется от сиде- рита и ферригидрита в поверхностных водах до их насыщенности в трещинно-жильных водах верхнепалеозойских гранитов кальцитом, доломитом, магнезитом, родохрозитом и тальком (рис. 5). В условиях антропогенного загрязнения отмечается рост степени насыщения радоновых вод относительно карбонатных и сульфатных минералов.

Выявлено, что воды группы I с общей минерализацией до 600 мг/дм ${ }^{3}$ являются ненасыщенными по отношению к карбонатным минералам, за исключением сидерита, что ранее отмечалось С.Л. Шварцевым для вод зоны гипергенеза [40]. С ростом общей минерализации антропогенно-измененных вод (группы II и III) от 600 до 1800 мг/дм ${ }^{3}$ наблюдается увеличение индексов насыщения, что приводит к их пересыщению относительно кальцита, доломита и сидерита. Поведение железосодержащих минеральных фаз в радоновых водах не имеет строгой связи с величиной их общей минерализации, поскольку железо обладает слабой (инертной) миграционной способностью и находится в растворе преимущественно $\mathrm{Fe}(\mathrm{II})$ в форме $\mathrm{Fe}^{2+}, \mathrm{FeHCO}_{3}{ }^{+}, \mathrm{FeCO}_{3}{ }^{0}$, а $\mathrm{Fe}(\mathrm{III})$ в виде $\mathrm{Fe}(\mathrm{OH})_{2}{ }^{+}$и $\mathrm{Fe}(\mathrm{OH})_{3}{ }^{0}$. Природа появления в подземных водах железа, марганца и кремния объясняется в основном природными факторами, отражающими климатические и гидрогеологические особенности исследуемой территории. Железо в подземных водах появляется в результате миграции его ионных форм из водовмещающих пород в восстановительной среде.

Широкое распространение сульфидной минерализации, слабая расчлененность рельефа, пологое залегание пород, замедляя водообмен, обеспечивают формирование восстановительной среды в сочетании с нейтральной или слабощелочной средой уже в зоне аэрации (рН вод изменяется от 6,8 до 8). Таким образом, высокое содержание железа и марганца связано с уменьшением окислительно-восстановительного потенциала (Eh) подземных вод, что является закономерным явлением в общей вертикальной гидрогеохимической зональности геологических структур. Присутствие в трещинно-жильных водах гранитов повышенных содержаний сульфат-иона и бария объясняет в большинстве случаев их насыщение баритом (рис. 5).

Индексы насыщения радоновых вод относительно соединений кремния показали, что при минерализации свыше 644 мг/дм ${ }^{3}$ происходит пересыщение раствора относительно кварца, халцедона и кристобалита, в то время как относительно аморфного кремнезема воды не насыщены. До этого момента кремний в водах связывается аутигенными минералами из раствора (воды насыщены относительно каолинита, Са- и $\mathrm{Mg}$-монтмориллонита и $\mathrm{Fe}$-сепиолита). Поэтому отмечается закономерный рост его средних концентраций с глубиной, которые растут от 3,4 мг/дм ${ }^{3}$ в поверхностных водах, составляя 6,5-7,5 мг/дм ${ }^{3}$ в порово-пластовых водах четвертичных отложений, достигая 8,3 мг/дм³ в водах зоны региональной трещиноватости, и до 11,7 мг/дм ${ }^{3}$ в минеральных радоновых водах. 

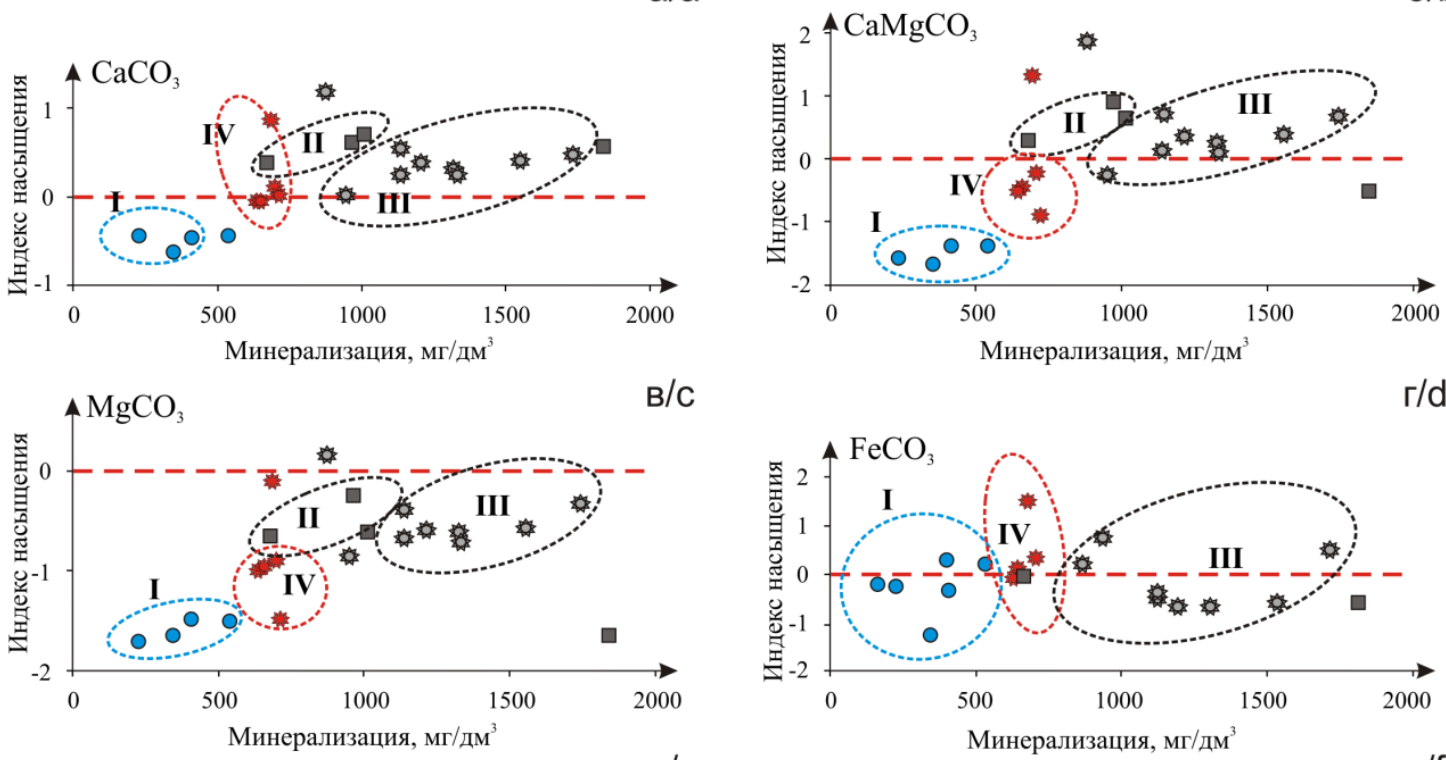

$\mathrm{B} / \mathrm{C}$

$r / d$
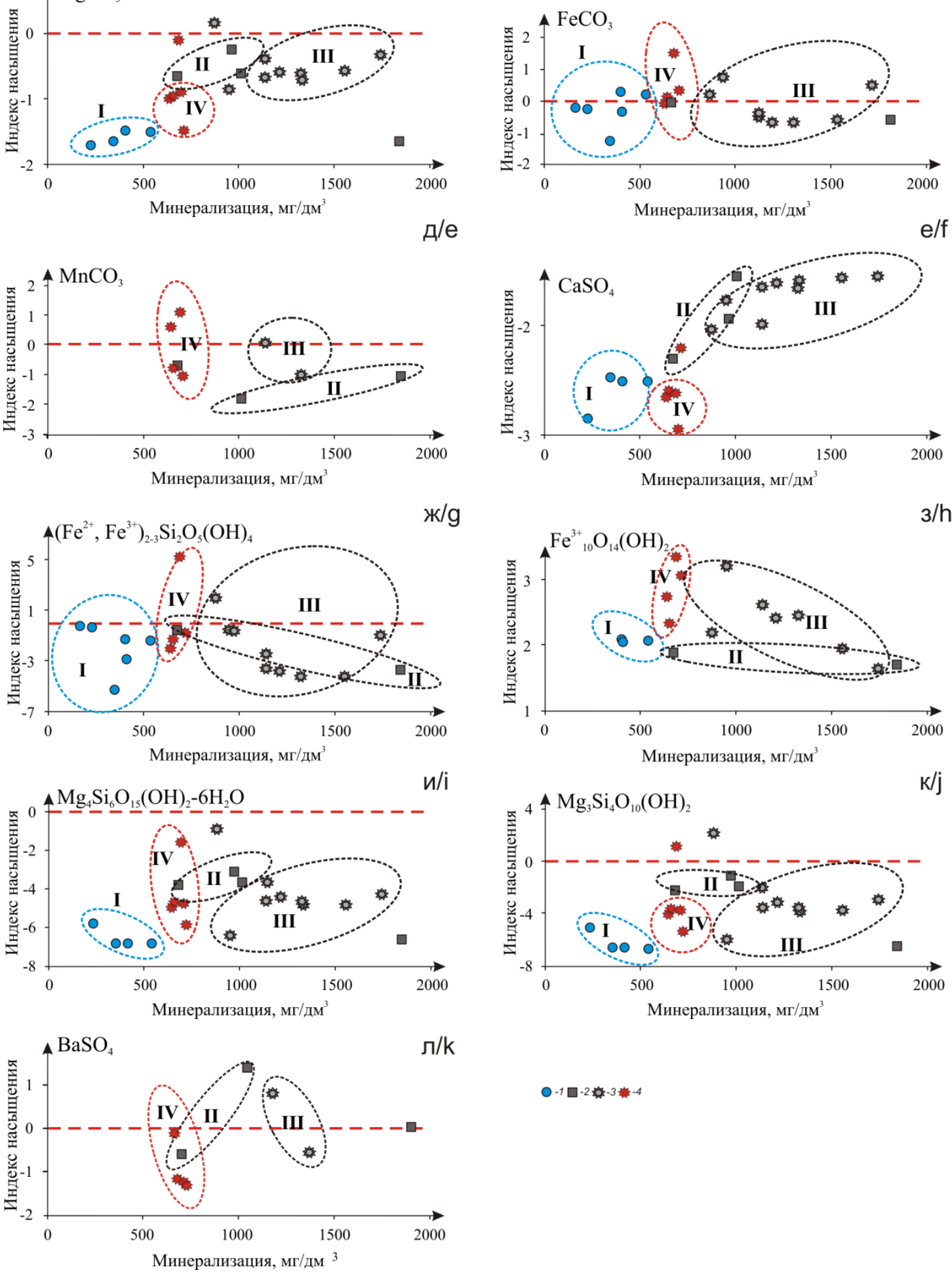

3/h

/ 
Рис. 5. Индексы насыщения радоновых вод к ряду минеральных фаз относительно их общей минерализации. Геохимические группы природных вод: 1 - поверхностные (группа I); 2 - порово-пластовые воды четвертичных отложений, в зоне подтопления в условиях антропогенного воздействия (группа II); 3 - воды зоны региональной трешиноватости верхнепалеозойских гранитов, в зоне подтопления в условиях антропогенного воздействия (группа III); 4 - трещинно-жильные воды верхнепалеозойских гранитов (минеральные радоновые) (2pynna IV)

Fig. 5. Saturation indices of radon waters for mineral phases and total mineralization. Geochemical groups of natural waters: 1 -surface (group I); 2 - pore-stratal waters of Quaternary sediments, in the flooding zone under conditions of anthropogenic impact (group II); 3 - waters of the zone of regional fracturing of the Upper Paleozoic granites, in the flooding zone under conditions of anthropogenic impact (group III); 4 - fracture-vein waters of the Upper Paleozoic granites (mineral radon) (group IV)

Различие в растворимости аморфного и кристаллического кремнеземов связано с высокой степенью упорядоченности структуры и качественно другим типом связи в кристаллических формах [41]. В большинстве случаев кремний поступает в воды в результате гидролиза алюмосиликатных минералов и чаще всего присутствует в молекулярно-диспергированном $\left(\mathrm{H}_{4} \mathrm{SiO}_{4}, \mathrm{H}_{2} \mathrm{SiO}_{3}\right)$, реже коллоидальном $\left(x \mathrm{SiO}_{2} \cdot y \mathrm{H}_{2} \mathrm{O}\right)$ состоянии [42]. Карбонатные минералы, как правило, являются реакционноспособными, и результаты геологоразведочных работ указывают на их наличие в водовмещающих отложениях [43]. Поэтому логичным продолжением дальнейших исследований по равновесиям в системе вода-порода будет детальное литолого-минералогическое изучение вмещающих пород, в первую очередь аутигенных минералов.

\section{Заключение}

Резюмируя вышесказанное, можно сделать следующие выводы:

1. Гидрогеологический разрез Каменского месторождения радоновых вод имеет двухъярусное строение. Верхний представлен поровыми водами четвертичных отложений, а нижний трещинножильными водами верхнепалеозойских гранитов. Радоновые воды месторождения подвержены значительному антропогенному загрязнению за счет процессов подтопления, которые затронули четвертичные отложения и воды зоны региональной трещиноватости гранитов. Диапазон содержаний радона в водах (163-1570 Бк/дм $\left.{ }^{3}\right)$ в соответствии с классификацией Н.И. Толстихина позволяет отнести их к классам от очень слаборадоновых до сильно радоновых.

2. Не подверженные антропогенному влиянию, минеральные радоновые трещинно-жильные воды гранитов холодные, собственно пресные $\mathrm{HCO}_{3}$ $\mathrm{Na}-\mathrm{Ca}$ и $\mathrm{HCO}_{3} \mathrm{Na}-\mathrm{Mg}-\mathrm{Ca}$ состава с величиной об-

\section{СПИСОК ЛИТЕРАТУРЫ}

1. Новиков Д.А., Сухорукова А.Ф., Корнеева Т.В Гидрогеология и гидрогеохимия Заельцовско-Мочищенского проявления радоновых вод (юг Западной Сибири) // Геодинамика и тектонофизика. - 2018. - Т. 9 - № 4. - С. 1255-1274.

2. Novikov D.A., Korneeva T.V. Microelements in radon waters of the Zaelsovsky field (the southern part of West Siberia) // Journal of Physics: Conference Series. - 2019. - V. 1172. - № 012096. щей минерализации 613,4-689,9 мг/дм³ и содержанием Si от 10,3 до 13,6 мг/дм ${ }^{3}$. Состав водорастворенных газов $-\mathrm{O}_{2}-\mathrm{N}_{2}$. Установленная активность ${ }^{222} \mathrm{Rn}$ изменяется от 1101 до $1570 \mathrm{Б \kappa /дм}{ }^{3}$, а содержания ${ }^{238} \mathrm{U}$ от $5,6 \cdot 10^{-3}$ до $6,5 \cdot 10^{-3}$ мг/дм ${ }^{3}$ и ${ }^{226} \mathrm{Ra}$ от $2,7 \cdot 10^{-9}$ до $1,8 \cdot 10^{-8}$ мг/дм ${ }^{3}$.

3. В более минерализованных водах образуются труднорастворимые карбонатные и сульфатные соединения, что сопровождается снижением в растворе простых катионных форм $\mathrm{Mg}^{2+}, \mathrm{Ca}^{2+}, \mathrm{Na}^{+}, \mathrm{Sr}^{2+}$ и $\mathrm{Ba}^{2+}$. В радоновых водах формы $\mathrm{Fe}(\mathrm{II})$ представлены в виде $\mathrm{Fe}^{2+}, \mathrm{FeHCO}_{3}^{+}, \mathrm{FeCO}_{3}{ }^{0}$, а $\mathrm{Fe}(\mathrm{III})$ в виде $\mathrm{Fe}(\mathrm{OH})_{2}^{+}$и $\mathrm{Fe}(\mathrm{OH})_{3}{ }^{0}$. Доминирующими формами миграции марганца является $\mathrm{Mn}^{2+}(43,71-99,99 \%), \mathrm{MnHCO}_{3}^{+}$ $(9,89-28,27 \%), \mathrm{MnCO}_{3}{ }^{0}(0,01-37,39), \mathrm{MnSO}_{4}{ }^{0}$ $(0,20-2,25 \%), \mathrm{MnCl}^{+}(0,04-1,12 \%)$ и $\mathrm{MnOH}^{+}$ $(0,01-0,05 \%)$. Тяжелые металлы $(\mathrm{Ni}$ и $\mathrm{Cu})$ мигрируют в виде свободных катионов $\left(\mathrm{Ni}^{2+}, \mathrm{Cu}^{2+}\right)$, гидрокарбонатных $\left(\mathrm{NiHCO}_{3}^{-}, \mathrm{CuHCO}_{3}^{-}\right)$и карбонатных $\left(\mathrm{NiCO}_{3}{ }^{0}, \mathrm{CuCO}_{3}{ }^{0}\right)$ комплексов. Медь также мигрирует в нейтральной гидроксидной форме $\mathrm{Cu}(\mathrm{OH})_{2}{ }^{0}$. Бериллий (1 класс опасности) мигрирует в форме гидроксокомплекса $\mathrm{Be}(\mathrm{OH})_{2}$.

4. В условиях антропогенного загрязнения отмечается рост степени насыщения радоновых вод относительно карбонатных и сульфатных минералов. Особенности геохимических типов вод определяют долевое распределение форм миграции химических элементов и усложнение состава равновесных минералов от ферригидрита и сидерита в поверхностных водах до их насыщения кальцитом, доломитом, баритом и родохрозитом в трещинножильных водах верхнепалеозойских гранитов.

Исследования проводились при финансовой поддержке проекта ФНИ № 0331-2019-0025 и Российского фонда фундаментальных исследований и Правительства Новосибирской области в рамках научного проекта № 19-45-540004.

3. Hydrogeological conditions and hydrogeochemistry of radon waters in the Zaeltsovsky-Mochishche zone of Novosibirsk, Russia / D.A. Novikov, F.F. Dultsev, R. Kamenova-Totzeva, T.V. Korneeva // Environmental Earth Sciences. - 2021. - V. 80. № 216 .

4. Novikov D.A., Dultsev F.F., Chernykh A.V. Role of water-rock interactions in the formation of the composition of radon waters of the Zaeltsovsky field (the southern part of West Siberia) // Journal of Physics: Conference Series. - 2020. - V. 1451. - № 012007. 
5. Изотопно-геохимические особенности проявления слаборадоновых вод «Инские источники» (юг Западной Сибири) Д.А. Новиков, Ю.Г. Копылова, Л.Г. Вакуленко, А.Ф. Сухорукова, А.Н. Пыряев, А.А. Максимова, Ф.Ф. Дульцев, А.В. Черных // Известия Томского политехнического университета. Инжиниринг георесурсов. - 2021. - Т. 332. - № 3. - С. 135-145.

6. Dissolved radon and uranium in groundwater in a potential coal seam gas development region (Richmond River Catchment, Australia) / M.L. Atkins, I.R. Santos, A. Perkins, D.T. Maher // Journal of Environmental Radioactivity. - 2016. - V. 154. - P. 83-92. URL: https://doi.org/10.1016/j.jenvrad.2016.01.014 (дата обращения 01.03.2021).

7. Hydrochemistry and $222 \mathrm{Rn}$ concentrations in spring waters in the Arid Zone El Granero, Chihuahua, Mexico / M. RenteríaVillalobos, A. Covarrubias-Muños, A. Pinedo-Álvarez, G. Manjon-Collado // Geosciences. - 2017. - V. 7 (1). - № 12.

8. Shilpaa G.M., Anandaramb B.N., Mohankumaric T.L. Measurement of $222 \mathrm{Rn}$ concentration in drinking water in the environs of Thirthahalli taluk, Karnataka, India // Journal of Radiation Research and Applied Sciences. - 2017. - V. 10. № 3. - P. 262-268.

9. Groundwater chemistry and radon-222 distribution in Jerba Island, Tunisia / F. Telahigue, B. Agoubi, F. Souid, A. Kharroubi // Journal of Environmental Radioactivity. - 2018. - V. 182. - P. 74-84.

10. Sherif M.I., Sturchioa N.C. Radionuclide geochemistry of groundwater in the Eastern Desert, Egypt // Applied Geochemistry. - 2018. - V. 93. - P. 69-80.

11. Bhattacharya P. Radon in the groundwater in the Amman-Zarqa Basin and related environments in Jordan / M.M. Abu-Khadera, A.T. Shawaqfeh, Z. Naddaf, J.P. Maity // Groundwater for Sustainable Development. - 2018. - V. 7. - P. 73-81.

12. Amiri V., Nakhaei M., Lak R. Using radon-222 and radium-226 isotopes to deduce the functioning of a coastal aquifer adjacent to a hypersaline lake in NW Iran // Journal of Asian Earth Sciences. 2017. - V. 147. - P. 128-147.

13. Radiological studies in the hot spring region of Mahallat, centra Iran / M. Beitollahi, M. Ghiassi-Nejad, A. Esmaeli, R. Dunker // Radiation Protection Dosimetry. - 2007. - V. 123 (4). - P. 505-508.

14. Bertolo A., Bigliotto C. Radon concentration in waters of geothermal Euganean basin-Veneto, Italy // Radiation Protection Dosimetry. - 2004. - V. 111 (4). - P. 355-358. URL: https://doi.org/10.1093/rpd/nch053 (дата обращения 01.03.2021).

15. Bohm C. Radon in Wasser-Uberblick fur den Kanton Graubunden // Jahresbericht Naturforschende Gesellschaft Graubunden. - 2002. V. 111 - P. 49-79.

16. Natural radioactivity levels in Andalusian spas / C. Duenas, M.C. Fernandez, C. Enraquez, J. Carretero, E. Liger // Water Research. - 1998. - V. 32 (8). - P. 2271-2278. URL http://dx.doi.org/10.1016/S0043-1354(97)00472-7 (дата обращения 01.03.2021)

17. Gurler O., Akar U., Kahraman A. Measurements of radon levels in thermal waters of Bursa, Turkey // Fresenius Environmental Bulletin. - 2010. - V. 19 (12). - P. 3013-3017.

18. Radon concentrations in hot spring waters in northern Venezuela A.D. Horvath, L.O. Bohus, F. Urbani, G. Marx, A. Piroth, E.D. Greaves // Journal of Environmental Radioactivity. - 2000. V. 47 (2). - P. 127-133.

19. Mittal S., Rani A., Mehra R. Radon levels in drinking water and soil samples of Jodhpur and Nagaur districts of Rajasthan, India // Applied Radiation and Isotopes. - 2016. - V. 113. - P. 53-59. URL: https://doi.org/10.1016/j.apradiso.2016.04.017 (дата обращения 01.03.2021)

20. Exposure to radon in the radon spa Niska Banja, Serbia J. Nikolov, N. Todorovic, T. Petrovic Pantic, S. Forkapic, D. Mrdja, I. Bikit, M. Krmar, M. Veskovic // Radiation Measurements. - 2012. - V. 47. - P. 443-450.

21. Correlations between radium and radon occurrence and hydrogeochemical features for various geothermal aquifers in northwestern Romania / C.A. Roba, D. Nita, C. Cosma, V. Codrea, S. Olah // Geothermics. - 2012. - V. 42. - P. 32-46.

22. Роль структурного фактора в распределении подземных вод с повышенным содержанием радона на юго-западном фланге Южно-Байкальской рифтовой впадины / К.Ж. Семинский, Ю.П. Бурзунова, А.К. Семинский, А.А. Бобров // Геодинамика и тектонофизика. - 2017. - Т. 8 - № 4. - С. 949-969.
23. Contribution of $222 \mathrm{Rn}$ bearing water to indoor radon and indoor air quality assessment in hot spring hotels of Guangdong, China / G. Song, X. Wang, D. Chen, Y. Chen // Journal of Environmental Radioactivity. - 2011. - V. 102 (4). - P. 400-406.

24. Геологическое строение и полезные ископаемые Западной Сибири / Ю.Н. Варкасин, В.Г. Свиридов, Н.А. Росляков, А.Т. Афанасьев, Г.А. Вавилихин, И.П. Васильев, В.И. Виниченко, А.Н. Леонов, А.И. Марус, Л.С. Михантьева, Г.В. Нестеренко, Г.Л. Самсонов, З.Я. Сердюк. - Новосибирск: Изд-во СО РАН, НИЦ ОИГГМ, 1998. - Т. 2. - 254 с.

25. Вериго Е.К., Быкова В.В., Гусев В.К. Заельцовское месторождение радоновых вод (Новосибирское Приобье) // Новые данные по геологии и полезным ископаемым Западной Сибири. 1979. - № 14. - C. 47-51.

26. Гусев В.К., Вериго Е.К. Радоновые воды Колывань-Томской складчатой зоны, их использование и охрана // Изменение природных условий под влиянием деятельности человека. Новосибирск: Наука, Сибирское отделение, 1984 - С. 99-107.

27. Посохов Е.В., Толстихин Н.И. Минеральные воды (лечебные, промышленные, энергетические). - М.: Недра, 1977. - 240 с.

28. Росляков Н.А., Жмодик С.М., Пахомов В.Г. Естественные радионуклиды в геологической среде Новосибирской области // Радиоактивность и радиоактивные элементы в среде обитания человека: Материалы IV Международной конференции. Томск, 4-8 июня 2013. - Томск: Изд-во Томского политехнического университета, 2013. - С. 461-464.

29. Долгушин А.П., Царук И.И. Урановорудный потенциал Центрально-Сибирского региона // Разведка и охрана недр. 2015. - № 10. - С. 28-34.

30. Царук И.И., Дундуков Н.Н. Основные вехи создания минерально-сырьевой базы урана России и Ближнего Зарубежья // Разведка и охрана недр. - 2015. - № 10. - С. 3-17.

31. Государственная геологическая карта Российской Федерации. Масштаб 1:1000000. Лист N 44. - СПб.: ФГБУ «ВСЕГЕИ», 2015.

32. Кох А.А., Новиков Д.А. Гидродинамические условия и вертикальная гидрогеохимическая зональность подземных вод в западной части Хатангского артезианского бассейна // Водные ресурсы. - 2014. - Т. 41. - № 4. - С. 375-385.

33. Новиков Д.А. Гидрогеологические предпосылки нефтегазоносности западной части Енисей-Хатангского регионального прогиба// Геодинамика и тектонофизика. - 2017. - Т. 8 № 4. - C. 881-901.

34. Novikov D.A. Hydrogeochemistry of the Arctic areas of Siberian petroleum basins // Petroleum Exploration and Development. 2017. - V. 44 (5). - P. 780-788.

35. Novikov D.A., Sukhorukova A.F. Hydrogeology of the northwestern margin of the West Siberian Artesian Basin // Arabian Journal of Geosciences. - 2015. - V. 8 (10). - P. 8703-8719.

36. Корнеева Т.В., Новиков Д.А. Механизмы накопления микроэлементов в радоновых водах Заельцовского месторождения (юг Западной Сибири) // Материалы Всероссийского совещания по подземным водам Востока России. - Новосибирск: ИПЦ НГУ, 2018. - С. 270-276.

37. Новиков Д.А., Деркачев А.С., Сухорукова А.Ф. Гидрогеохимия Заельцовско-Мочищенского проявления радоновых вод // Интерэкспо Гео-Сибирь. - 2019. - Т. 2. - № 1. - С. 125-132.

38. Перельман А.И. Геохимия ландшафта. изд. 2-е. - М.: Высшая школа, 1975. - $342 \mathrm{c}$.

39. Григорьев Н.А. Распределение химических элементов в верхней части континентальной коры // Уральский геологический журнал. - 2010. - № 3 (75). - С. 85-90.

40. Шварцев С.Л. Общая гидрогеология. - М.: Недра, 1996. - 423 с.

41. Зверев В.П. Роль подземных вод в миграции химических элементов. - М.: Недра, 1982. -186 с.

42. Лукнер Л., Шестаков В.М. Моделирование миграции подземных вод. - М.: Недра, 1986. - 208 с.

43. Минерагения области сочленения Салаира и КолываньТомской складчатой зоны / Н.А. Росляков, Ю.Г. Щербаков, Л.В. Алабин, Г.В. Нестеренко, А.Ю. Калинин, Н.В. Рослякова, И.П. Васильев, А.И. Неволько, С.Р. Осинцев. - Новосибирск: Изд-во СО РАН, филиал «Гео», 2001. - 243 с.

Поступила 10.03.2021 г. 


\section{Информация об авторах}

Новиков Д.А., кандидат геолого-минералогических наук, заведующий лабораторией гидрогеологии осадочных бассейнов Сибири Института нефтегазовой геологии и геофизики им. А.А. Трофимука СО РАН; доцент кафедры геологии месторождений нефти и газа и кафедры общей и региональной геологии Новосибирского национального исследовательского государственного университета.

Сухорукова A.Ф., кандидат геолого-минералогических наук, научный сотрудник лаборатории гидрогеологии осадочных бассейнов Сибири Института нефтегазовой геологии и геофизики им. А.А. Трофимука СО РАН; доцент кафедры общей и региональной геологии Новосибирского национального исследовательского государственного университета.

Корнеева T.B., кандидат геолого-минералогических наук, научный сотрудник лаборатории геоэлектрохимии Института нефтегазовой геологии и геофизики им. А.А. Трофимука СО РАН.

Каменова-Тоцева P.M., доцент, заведующая лабораторией Мониторинга публичного воздействия, руководитель аккредитационного центра типа А Национального центра радиобиологии и радиационной защиты.

Максимова A.A., студент, Новосибирский национальный исследовательский государственный университет.

Деркачев A.C., студент, Новосибирский национальный исследовательский государственный университет.

Дульцев Ф.Ф., научный сотрудник лаборатории гидрогеологии осадочных бассейнов Сибири Института нефтегазовой геологии и геофизики им. А.А. Трофимука СО РАН.

Черных $\boldsymbol{A}$.В., научный сотрудник лаборатории гидрогеологии осадочных бассейнов Сибири Института нефтегазовой геологии и геофизики им. А.А. Трофимука СО РАН. 
UDC 556.3(571.1)

\section{HYDROGEOLOGY AND HYDROGEOCHEMISTRY OF THE «KAMENSKOE» FIELD OF RADON-RICH WATERS (NOVOSIBIRSK)}

\author{
Dmitry A. Novikov1,2, \\ NovikovDA@ipgg.sbras.ru
}

Anna F. Sukhorukova1,2, SukhorukovaAF@ipgg.sbras.ru

Tatyana V. Korneeva', KorneevaTV@ipgg.sbras.ru

\section{Rositza M. Kamenova-Totzeva ${ }^{3}$,} r.totzeva@ncrrp.org

\author{
Anastasia A. Maksimova², \\ rock.nastaya64@gmail.com
}

\author{
Anton S. Derkachev², \\ a.derkachev@g.nsu.ru
}

Fedor F. Dultsev ${ }^{1}$, DultsevFF@ipgg.sbras.ru

\section{Anatoliy V. Chernykh ${ }^{1}$, ChernykhAV@ipgg.sbras.ru}

1 Trofimuk Institute of Petroleum Geology and Geophysics of SB of RAS,

3/6, Koptyug avenue, Novosibirsk, 630090, Russia.

2 Novosibirsk State University,

1, Pirogov street, Novosibirsk, 630090, Russia.

3 National Center of Radiobiology and Radiation Protection,

3, «St. George Sofiyski» street, Sofia, 1606, Bulgaria.

The relevance of the research consists in obtaining new information on hydrogeology and hydrogeochemistry of underexplored fields Novosibirsk radon waters in the south of Western Siberia. Novosibirsk is one of those few cities in Russia that were laid on granites - a source of radon emanation $\left({ }^{222} \mathrm{Rn}\right)$. The study area is confined to the inner area of the large Novosibirsk granitoid massif. There were no scientific generalizations of the available factual material.

The aim of the research is to identify the features of the hydrogeological structure and hydrogeochemistry of the mineral hydro-radon occurrence "Kamenskoe» and to study the forms of migration of chemical elements and the saturation degree to minerals.

Methods. Sampling was carried out in accordance with generally accepted methods. Compilation and analysis of hydrogeochemical data was carried out using the software Microsoft Excel, STATISTICA, SURFER, Grid Master. In the environment of Visual Minteq and WATEQ4f software packages, physicochemical calculations of the migration forms of chemical elements in radon waters and the degree of their saturation to a number of rock-forming minerals were performed.

Results. In the hydrogeological section of the "Kamenskoe» hydro-radon occurrence two aquifers: pore water of Quaternary aquifer and fissure-vein waters of Upper Paleozoic granites, were established (from top to bottom). In the central part of Novosibirsk, the infiltration of atmospheric precipitation is complicated, the natural regime of groundwater supply is disturbed. Pore-stratal waters of Quaternary sediments, waters of the zone of regional fracturing and fracture-vein waters of Upper Paleozoic granites are located in a common mixing area, which is influenced by flooding and anthropogenic pollution. Thus, in the water-bearing complex of the Upper Paleozoic granites, two hydrogeochemical zones are distinguished: the upper one is the waters of the regional fracturing zone in the flooding area under anthropogenic impact, and the lower one is the fractured-vein mineral radon waters. Mineral radon fissure-vein waters of granites are not subject to anthropogenic influence and are installed in well no. 4p (interval 73-74 m) and in well no. 16 at depths from 73 to $128 \mathrm{~m}$. They are cold, fresh, $\mathrm{HCO}_{3} \mathrm{Na}-\mathrm{Ca}$ and $\mathrm{HCO}_{3} \mathrm{Na}-\mathrm{Mg}$-Ca composition with TDS from 613,4 to $689,9 \mathrm{mg} / \mathrm{dm}^{3}$ and silicon content 10,3-13,6 mg/dm $\mathrm{dmey}^{3}$. The are characterized by $\mathrm{pH}$ from neutral to slightly alkaline $(6,9-7,8)$ and oxygen-nitrogen composition of water-dissolved gases. The established activity of ${ }^{222} \mathrm{Rn}$ varies in the range of $1101-1570 \mathrm{~Bq} / \mathrm{dm}^{3}$ (strongly radon waters according to the classification of N.I. Tolstikhin); content: ${ }^{238} \mathrm{U}$ from $5,6 \cdot 10^{-3}$ to $6,5 \cdot 10^{-3} \mathrm{mg} / \mathrm{dm}^{3}$ and ${ }^{226} \mathrm{Ra}$ from $2,7 \cdot 10^{-9}$ to $1,8 \cdot 10^{-8} \mathrm{mg} / \mathrm{dm}^{3}$. With an increase in the total mineralization of radon waters, the proportion of simple cationic forms of $\mathrm{Mg}^{2+}, \mathrm{Ca}^{2+}, \mathrm{Na}^{+}, \mathrm{Sr}^{2+}, \mathrm{Ba}^{2+}$ in solution decreases, which is associated with the formation of hardly soluble carbonate and sulfate compounds. In radon waters, $\mathrm{Fe}(\mathrm{II})$ forms are presented as $\mathrm{Fe}^{2+}, \mathrm{FeHCO}_{3}{ }^{+}, \mathrm{FeCO} 3^{0}$. Ferrum (III) migrates in the form of positively charged hydroxo complexes $\mathrm{Fe}(\mathrm{OH})_{2}{ }^{+}$and neutral $\mathrm{Fe}(\mathrm{OH})_{3}{ }^{0}$. Among the forms of manganese migration, the simple cation $\mathrm{Mn}^{2+}$ (43,71-99,99\%) dominates, the remaining forms are represented by $\mathrm{MnHCO}_{3}{ }^{+}(9,89-28,27 \%)$ and $\mathrm{MnCO}_{3}{ }^{0}(0,01-37,39)$, to an even lesser extent $\mathrm{MnSO}_{4}{ }^{0}(0,20-2,25 \%), \mathrm{MnCl}^{+}(0,04-1,12 \%)$ and $\mathrm{MnOH}^{+}(0,01-0,05 \%)$. The chemical forms of migration of heavy metals (nickel and copper) are presented in the form of free cations $\left(\mathrm{Ni}^{2+}, \mathrm{Cu}^{2+}\right)$, hydrocarbonate $\left(\mathrm{NiHCO}_{3}\right.$, $\mathrm{CuHCO}_{3}{ }^{-}$) and carbonate $\left(\mathrm{NiCO}_{3}{ }^{0}, \mathrm{CuCO}_{3}{ }^{\circ}\right.$ ) complexes. Copper also migrates in the neutral form $\mathrm{Cu}(\mathrm{OH})_{2}{ }^{0}$. Beryllium (hazard class 1) migrates in the form of the hydroxo complex $\mathrm{Be}(\mathrm{OH})_{2}$. The established features of the geochemical types of waters, the proportional distribution of forms and coefficients of water migration of chemical elements revealed the complication of the composition of equilibrium minerals from siderite, ferrihydrite, and greenalite in surface waters to saturation with calcite, dolomite, magnesite, rhodochrosite, and talc in fractured vein waters of the Upper Paleozoic granites. The forms of migration of chemical elements determine the mechanisms of dissolution/precipitation of mineral compounds.

\section{Key words:}

Hydrogeochemistry, radon waters, uranium, radium, radon, microcomponents, forms of migration, saturation indices, the «Kamenskoe» hydro-radon occurrence, Novosibirsk, Western Siberia.

The research was financially supported by the FSR № 0331-2019-0025 and the Russian Foundation for Basic Research and Governments of the Novosibirsk Region as part of a science project no. 19-45-540004. 


\section{REFERENCES}

1. Novikov D.A., Sukhorukova A.F., Korneeva T.V. Hydrogeology and hydrogeochemistry of the Zaeltsovsko-Mochishchensky zone of radon waters in the southern West Siberia. Geodynamics \& Tectonophysics, 2018, vol. 9 (4), pp. 1255-1274. In Rus.

2. Novikov D.A., Korneeva T.V. Microelements in radon waters of the Zaelsovsky field (the southern part of West Siberia). Journal of Physics: Conference Series, 2019, vol. 1172, no. 012096.

3. Novikov D.A., Dultsev F.F., Kamenova-Totzeva R., Korneeva T.V. Hydrogeological conditions and hydrogeochemistry of radon waters in the Zaeltsovsky-Mochishche zone of Novosibirsk, Russia. Environmental Earth Sciences, 2021, vol. 80, no. 216.

4. Novikov D.A., Dultsev F.F., Chernykh A.V. Role of water-rock interactions in the formation of the composition of radon waters of the Zaeltsovsky field (the southern part of West Siberia). Journal of Physics: Conference Series, 2020, vol. 1451, no. 012007.

5. Novikov D.A., Kopylova Yu.G., Vakulenko L.G., Sukhorukova A.F Pyryaev A.N., Maksimova A.A., Dultsev F.F., Chernykh A.V. Isotope geochemical features of occurrence of low-radon waters «Inskie springs» (south-western Siberia). Bulletin of the Tomsk Polytechnic University. Geo Assets Engineering, 2021, vol. 332, no. 3, pp. 135-145. In Rus.

6. Atkins M.L., Santos I.R., Perkins A., Maher D.T. Dissolved radon and uranium in groundwater in a potential coal seam gas development region (Richmond River Catchment, Australia). Journal of Environmental Radioactivity, 2016, vol. 154, pp. 83-92. Available at: https://doi.org/10.1016/j.jenvrad.2016.01.014 (accessed 1 March 2021).

7. Rentería-Villalobos M., Covarrubias-Muños A., Pinedo-Álvarez A., Manjon-Collado G. Hydrochemistry and ${ }^{222} \mathrm{Rn}$ Concentrations in Spring Waters in the Arid Zone El Granero, Chihuahua, Mexico. Geosciences, 2017, vol. 7 (1), no. 12.

8. Shilpaa G.M., Anandaramb B.N., Mohankumaric T.L. Measurement of ${ }^{222} \mathrm{Rn}$ concentration in drinking water in the environs of Thirthahalli taluk, Karnataka, India. Journal of Radiation Research and Applied Sciences, 2017, vol. 10, no. 3, pp. 262-268.

9. Telahigue F., Agoubi B., Souid F., Kharroubi A. Groundwater chemistry and radon-222 distribution in Jerba Island, Tunisia. Journal of Environmental Radioactivity, 2018, vol. 182, pp. 74-84

10. Sherif M.I., Sturchioa N.C. Radionuclide geochemistry of groundwater in the Eastern Desert, Egypt. Applied Geochemistry, 2018, vol. 93, pp. 69-80.

11. Abu-Khadera M.M., Shawaqfeh A.T., Naddaf Z., Maity J.P., Bhattacharya P. Radon in the groundwater in the Amman-Zarqa Basin and related environments in Jordan. Groundwater for Sustainable Development, 2018, vol. 7, pp. 73-81.

12. Amiri V., Nakhaei M., Lak R. Using radon-222 and radium-226 isotopes to deduce the functioning of a coastal aquifer adjacent to a hypersaline lake in NW Iran. Journal of Asian Earth Sciences, 2017, vol. 147, pp. 128-147.

13. Beitollahi M., Ghiassi-Nejad M., Esmaeli A., Dunker R. Radiological studies in the hot spring region of Mahallat, central Iran. Radiation Protection Dosimetry, 2007, vol. 123 (4), pp. 505-508.

14. Bertolo A., Bigliotto C. Radon concentration in waters of geothermal Euganean basin-Veneto, Italy. Radiation Protection Dosimetry, 2004, vol. 111 (4), pp. 355-358. Available at: https://doi.org/10.1093/rpd/nch053 (accessed 1 March 2021).

15. Bohm C. Radon in Wasser-Uberblick fur den Kanton. Graubunden. Jahresbericht Naturforschende Gesellschaft Graubunden, 2002, vol. 111, pp. 49-79.

16. Duenas C., Fernandez M.C., Enraquez C., Carretero J., Liger E. Natural radioactivity levels in Andalusian spas. Water Research, 1998, vol. 32 (8), pp. 2271-2278. Available at: http://dx.doi.org/10.1016/S0043-1354(97)00472-7 (accessed 1 March 2021)

17. Gurler O., Akar U., Kahraman A. Measurements of radon levels in thermal waters of Bursa, Turkey. Fresenius Environmental Bulletin, 2010, vol. 19 (12), pp. 3013-3017.

18. Horvath A.D., Bohus L.O., Urbani F., Marx G., Piroth A., Greaves E.D. Radon concentrations in hot spring waters in northern Venezuela. Journal of Environmental Radioactivity, 2000, vol. 47 (2), pp. 127-133.

19. Mittal S., Rani A., Mehra R. Radon levels in drinking water and soil samples of Jodhpur and Nagaur districts of Rajasthan, India.
Applied Radiation and Isotopes, 2016, vol. 113, pp 53-59. Available at: https://doi.org/10.1016/j.apradiso.2016.04.017 (accessed 1 March 2021).

20. Nikolov J., Todorovic N., Petrovic Pantic T., Forkapic S., Mrdja D., Bikit I., Krmar M., Veskovic M. Exposure to radon in the radon spa Niska Banja, Serbia. Radiation Measurements, 2012, vol. 47 , pp. 443-450.

21. Roba C.A., Nita D., Cosma C., Codrea V., Olah S. Correlations between radium and radon occurrence and hydrogeochemical features for various geothermal aquifers in northwestern Romania. Geothermics, 2012, vol. 42, pp. 32-46.

22. Seminsky K.Zh., Burzunova Yu.P., Seminsky A.K., Bobrov A.A. Role of the structural factor in the distribution of high-radon groundwater in the southwestern flank of the South Baikal rift basin. Geodynamics \& Tectonophysics, 2017, vol. 8 (4), pp. 949-969. In Rus.

23. Song G., Wang X., Chen D., Chen Y. Contribution of 222Rn bearing water to indoor radon and indoor air quality assessment in hot spring hotels of Guangdong, China. Journal of Environmental Radioactivity, 2011, vol. 102 (4), pp. 400-406.

24. Varkasin Yu.N., Sviridov V.G., Roslyakov N.A., Afanasyev A.T., Vavilikhin G.A., Vasiliev I.P., Vinichenko V.I., Leonov A.N., Marus A .I., Mikhantieva L.S., Nesterenko G.V., Samsonov G.L., Serdyuk Z.Ya. Geolodicheskoe stroenie i poleznye iskopaemye Zapadnoy Sibiri [Geological structure and minerals of Western Siberia]. Novosibirsk, SB RAS, SIC OIGGM Publ., 1998. Vol. 2, $254 \mathrm{p}$.

25. Verigo E.K., Bykova V.V., Gusev V.K. Zaeltsovskoe mestorozdenie radonovykh vod (Novosibirskoe Priobye) [Zaeltsovsky deposit of radon waters (Novosibirsk Priobye)]. New data on geology and minerals of Western Siberia, 1979, Iss. 14, pp. 47-51.

26. Gusev V.K., Verigo E.K. Radonovye vody Kolyvan-Tomskoy skladchatoy zony, ikh ispolzovanie i okhrana [Radon waters of the Kolyvan-Tomsk fold zone, their use and protection]. Izmenenie prirodnykh uslovy pod vliyaniem deyatelnosti cheloveka [Change in natural conditions under the influence of human activity]. Novosibirsk, Nauka, Siberian Branch, 1984. pp. 99-107.

27. Posokhov E.V, Tolstikhin N.I. Mineralnye vody (lechebnye, promyshlennye, energeticheskie) [Mineral waters (healing, industrial, energy)]. Moscow, Nedra Publ., 1977. 240 p.

28. Roslyakov N.A., Zhmodik S.M., Pakhomov V.G. Prirodnye radionuklidy v geologicheskoy srede Novosibirskoy oblasti [Natural radionuclides in the geological environment of the Novosibirsk region]. Radioaktivnost $i$ radioaktivnye elementy $v$ srede cheloveka. Materialy IV Mezhdunarodnoy konferentsii [Radioactivity and radioactive elements in the human environment. Materials of the IV International Conference]. Tomsk, June 4-8, 2013. Tomsk, Tomsk Polytechnic University Publ. house, 2013. pp. 461-464.

29. Dolgushin A.P., Tsaruk I.I. Uranium ore potential of the Central Siberian region. Exploration and protection of mineral resources, 2015, no. 10, pp. 28-34. In Rus.

30. Tsaruk I.I., Dundukov N.N. The main milestones of creating the mineral resource base of uranium in Russia and the Near Abroad. Exploration and protection of mineral resources, 2015, no. 10, pp. 3-17. In Rus.

31. Gosudarstvennaya geologicheskaya karta Rossiyskoy Federatsii. Masshtab 1:1000000 [State Geological map of the Russian Federation. Scale 1:1000000]. List N 44. St. Petersburg, FSBI «VSEGEI», 2015

32. Kokh A.A., Novikov D.A. Hydrodynamic conditions and vertical hydrogeochemical zonality of groundwater in the Western Khatanga Artesian Basin. Water Resources, 2014, vol. 41, no. 4, pp. 396-405. In Rus.

33. Novikov D.A. Hydrogeological conditions for the presence of oil and gas in the western segment of the Yenisei-Khatanga regional trough. Geodynamics and Tectonophysics, 2017, vol. 8, no. 4, pp. 881-901. In Rus.

34. Novikov D.A. Hydrogeochemistry of the Arctic areas of Siberian petroleum basins. Petroleum Exploration and Development, 2017, vol. 44 (5), pp. 780-788.

35. Novikov D.A., Sukhorukova A.F. Hydrogeology of the northwestern margin of the West Siberian Artesian Basin. Arabian Journal of Geosciences, 2015, vol. 8 (10), pp. 8703-8719.

36. Korneeva T.V., Novikov D.A. Mekhanizmy nakopleniya mikroelementov v radonovykh vodakh Zaeltsovskogo mestorozhdeniya 
(yug Zapadnoy Sibiri) [Mechanisms for accumulation of trace elements in radon waters of the Zaeltsovsky deposit (south of Western Siberia)]. Materialy Vserossiyskogo soveshchaniya po podzemnym vodam Vostoka Rossii [Materials of the All-Russian Meeting on Groundwaters of the East of Russia]. Novosibirsk, CPI NSU Publ., 2018. pp. 270-276.

37. Novikov D.A., Derkachev A.S., Sukhorukova A.F. Hydrogeochemistry of the Zaeltsov-Mochischen manifestation of radon waters. Interexpo Geo-Siberia, 2019, vol. 2, no. 1, pp. 125-132. In Rus.

38. Perelman A.I. Geokhimiya landshafta [Landscape geochemistry]. Moscow, Vysshaya shkola Publ., 1975. 342 p.

39. Grigoryev N.A. Raspredelenie khimicheskikh elementov v verkhney chasti kontinentalnoy kory [Distribution of chemical elements in the upper continental crust]. Uralskiy geologicheskiy zhurnal, 2010, no. 3 (75), pp. 85-90.
40. Shvartsev S.L. Obshchaya gidrogeologiya [General hydrogeology]. Moscow, Nedra Publ., 1996. 423 p.

41. Zverev V.P. Rol podzemnykh vod v khimicheskikh veshchestvakh [The role of groundwater in migration of chemical elements]. Moscow, Nedra Publ., 1982. 186 p.

42. Lukner L., Shestakov V.M. Modelirovanie prostranstva podzemnykh vod [Modeling groundwater migration]. Moscow, Nedra Publ., 1986. 208 p.

43. Roslyakov N.A., Scherbakov Yu.G., Alabin L.V., Nesterenko G.V., Kalinin A.Yu., Roslyakova N.V., Vasiliev I.P., Nevolko A.I., Osintsev S.R. Minerageniya oblasti sochleneniya Salaira i Kolyvan-Tomskoy skladchatoy zony [Minerageny of the joint area of Salair and Kolyvan-Tomsk fold zone]. Novosibirsk, SB RAS Publ., Geo branch, 2001. 243 p.

Received: 10 March 2021.

\section{Information aboit the author}

Dmitry A. Novikov, Cand. Sc., head of the laboratory, Trofimuk Institute of Petroleum Geology and Geophysics of Siberian Branch of Russian Academy of Sciences; associate professor, Novosibirsk State University.

Anna F. Sukhorukova, Cand. Sc., researcher, Trofimuk Institute of Petroleum Geology and Geophysics of Siberian Branch of Russian Academy of Sciences; associate professor, Novosibirsk State University.

Tatyana V. Korneeva, Cand. Sc., researcher, Trofimuk Institute of Petroleum Geology and Geophysics of Siberian Branch of Russian Academy of Sciences.

Rositza M. Kamenova-Totzeva, associate professor, head of Public Exposure Monitoring Laboratory, head of accredited inspection body type A, National Center of Radiobiology and Radiation Protection, Bulgaria.

Anastasia A. Maksimova, student, Novosibirsk State University.

Anton S. Derkachev, student, Novosibirsk State University.

Fedor F. Dultsev, research associate, Trofimuk Institute of Petroleum Geology and Geophysics of Siberian Branch of Russian Academy of Sciences.

Anatoliy $\boldsymbol{V}$. Chernykh, research associate, Trofimuk Institute of Petroleum Geology and Geophysics of Siberian Branch of Russian Academy of Sciences. 